\title{
Provenance of sediments from Barra del Tordo and Tesoro beaches, Tamaulipas State, northwestern Gulf of Mexico
}

\author{
Mayla A. Ramos-Vázquez ${ }^{1}$ (D) and John S. Armstrong-Altrin ${ }^{2^{*}}$ (D)
}

\begin{abstract}
The mineralogy, bulk sediment geochemical composition, and U-Pb ages of detrital zircons retrieved from the Barra del Tordo (Tordo) and Tesoro beach sediments in the northwestern Gulf of Mexico were analyzed to determine their provenance. The beach sediments are mainly composed of quartz, ilmenite, magnetite, titanite, zircon, and anorthite. The weathering proxies such as the Chemical Index of Alteration (CIA), Chemical Index of Weathering (CIW), and Plagioclase Index of Alteration (PIA), reveal a moderate-to-high intensity of weathering in the source area. The chondrite-normalized rare earth element (REE) patterns are similar to felsic igneous rocks, with large negative europium anomaly $\left(\mathrm{Eu} / \mathrm{Eu}^{*}=\sim 0.47-0.80\right.$ and $\sim 0.57-0.67$ in the Tordo and Tesoro beach sediments, respectively).

Three major zircon U-Pb age groups are identified in the Tordo and Tesoro beach sediments, i.e., Proterozoic $(\sim$ 2039-595 Ma), Mesozoic ( 244-70.3 Ma), and Cenozoic ( 65.9-1.2 Ma). The differences of the zircon age spectrum between the Tordo and Tesoro beach sediments are not significant. The comparison of zircon U-Pb ages in this study with ages of potential source terranes suggests that the Mesozoic and Cenozoic zircons of the studied Tordo and Tesoro beach sediments were derived from the Eastern Alkaline Province (EAP) and Mesa Central Province (MCP). Similarly, the likely sources for the Proterozoic zircons were the Sierra Madre Oriental (SMOr) and Oaxaquia in the northwestern Gulf of Mexico. The results of this study further indicate that the sediments delivered to the beaches by rivers and redistributed by longshore currents were crucial in determining the sediment provenance.
\end{abstract}

Keywords: Geochemistry, Sedimentary provenance, Zircon U-Pb, Beach sediment, Rare earth elements, Mexico

\section{Introduction}

The geochemistry of beach sediments in the Gulf of Mexico have been studied by various authors (RosalesHoz et al. 2015; Machain-Castillo et al. 2019; Ayala-Pérez et al. 2021; Kasper-Zubillaga et al. 2021), whereas the U$\mathrm{Pb}$ ages of detrital zircons from the Gulf of Mexico coastal sediments have not been studied extensively. Nevertheless, $\mathrm{U}-\mathrm{Pb}$ ages of zircon grains in volcanic rocks from various terranes in Mexico such as Cuicateco, Oaxacan Complex, Xolapa Complex, Mesa Central Province, and Eastern

\footnotetext{
* Correspondence: armstrong@cmarl.unam.mx; john_arms@yahoo.com ¿2Universidad Nacional Autónoma de México, Instituto de Ciencias del Mar y Limnología, Unidad de Procesos Oceánicos y Costeros, Ciudad Universitaria, 04510 Ciudad de México, Mexico

Full list of author information is available at the end of the article
}

Alkaline Province were widely studied (Solari et al. 2004; Rubio-Cisneros and Lawton 2011; Lawton and Molina-Garza 2014; Juárez-Arriaga et al. 2019; Sieck et al. 2019; Barboza-Gudiño et al. 2020; Torres-Sánchez et al. 2020; Verma et al. 2021).

The mineralogical and geochemical compositions of detrital sediments are commonly used to investigate the provenance, weathering, and tectonic setting of source area (e.g. Cullers et al. 1988; Chaudhuri et al. 2018, 2020; Critelli 2018; Al-Kaaby and Albadran 2020; Banerjee et al. 2020; Rivera-Gómez et al. 2020; Critelli et al. 2021; Karlik et al. 2021). Although detrital sediments are influenced by diagenesis and recycling, their mineral and geochemistry composition is primarily

\section{Springer Open}

(0) The Author(s). 2021 Open Access This article is licensed under a Creative Commons Attribution 4.0 International License, which permits use, sharing, adaptation, distribution and reproduction in any medium or format, as long as you give appropriate credit to the original author(s) and the source, provide a link to the Creative Commons licence, and indicate if changes were made. The images or other third party material in this article are included in the article's Creative Commons licence, unless indicated otherwise in a credit line to the material. If material is not included in the article's Creative Commons licence and your intended use is not permitted by statutory regulation or exceeds the permitted use, you will need to obtain permission directly from the copyright holder. To view a copy of this licence, visit http://creativecommons.org/licenses/by/4.0/. 
depended on source rocks. The immobile trace elements like REE, $\mathrm{Cr}, \mathrm{Hf}, \mathrm{Nb}, \mathrm{Ni}$, Th, and $\mathrm{V}$ are highly reliable indicators to differentiate sediments derived from felsic and/or mafic igneous rocks (Critelli et al. 1997, 2003; Zeng et al. 2019; Arribas et al. 2000; Cullers 2000). Similarly, chondrite-normalized REE patterns and the $\mathrm{Eu}$ anomaly are also extensively utilized in various studies to infer source rock characteristics (e.g. Bankole et al. 2020; Chaudhuri et al. 2020).

Detrital zircon $\mathrm{U}-\mathrm{Pb}$ age has become a common method to investigate zircon origin and to further discriminate source terranes (e.g. Lee et al. 2015; McRivette et al. 2019; Wang et al. 2020; Armstrong-Altrin et al. 2021). Zircon is a common mineral in acidic rocks, and due to its resistance capacity against weathering and thermal alteration, zircon retains $\mathrm{U}-\mathrm{Pb}$ isotopic signatures related to their origin and parent rocks (Potter-McIntyre et al. 2018; Dew et al. 2019). Numerous studies proved that detrital zircon $\mathrm{U}-\mathrm{Pb}$ geochronology is a powerful tool to investigate sediment provenance and their transport pathway (e.g. Gärtner et al. 2017; Hoskin and Ireland 2000; Al-Juboury et al. 2020). Besides, a few studies also documented the importance of the combination of the zircon $\mathrm{U}-\mathrm{Pb}$ age and sediment geochemistry to infer provenance and to locate source terranes (Turzewski et al. 2020; Zeng et al. 2020).

In this study, the mineralogy, bulk sediment composition, and $\mathrm{U}-\mathrm{Pb}$ ages of detrital zircons retrieved from the Barra del Tordo and Tesoro beaches, northwestern Gulf of Mexico are analyzed for the aims (1) to investigate the sediment provenance and (2) to identify the source terranes supplying sediments to the beach areas.

\section{Study area and geology}

Forty sediment samples (3 kg each) were collected in the Barra del Tordo $\left(23^{\circ} 07^{\prime} 30.78^{\prime \prime} \mathrm{N}-97^{\circ} 45^{\prime} 53.04^{\prime \prime} \mathrm{W}\right)$ and Tesoro $\left(22^{\circ} 29^{\prime} 42.39^{\prime \prime} \mathrm{N}-97^{\circ} 51^{\prime} 7.99^{\prime \prime} \mathrm{W}\right)$ beaches, located at the Tamaulipas State, the northwestern part of the Gulf of Mexico (Fig. 1). A 1-cm-thick top layer of the beach sand was removed before collecting the samples. Approximately a $100 \mathrm{~m}$ interval was maintained between sample locations. Metamorphic rocks from the Precambrian to the Paleozoic, marine sedimentary rocks from the Paleozoic to the Quaternary, igneous rocks of the Cenozoic age, and the unconsolidated Quaternary sediments are outcropped in the Tamaulipas State (Demant and Robin 1975; Rubio-Cisneros and Lawton 2011). The sediments in the coastal plain in the northwestern Gulf of Mexico mainly consist of (1) Mesozoic clastic (sandstone, siltstone, and shale) and calcareous (limestone) sedimentary rocks, and (2) Cenozoic volcanic rocks, which belong to the Sierra Madre Oriental Province (Demant and Robin 1975; Hudson 2003). The Pánuco, Tamesí, and Soto la Marina River drainage basins consist of arid to semi-arid Mesa Central Province, Oaxacan Complex, the north-south trending Sierra Madre Oriental, and the Gulf Coastal Plain.

In summer, longshore surface currents have a northward flow direction with an average velocity of $4.5 \mathrm{~cm} / \mathrm{s}$. In winter, longshore surface currents flow towards the south with an average velocity of $6 \mathrm{~cm} / \mathrm{s}$. Higher wind velocities were recorded during summer, which vary from $3.0 \mathrm{~m} / \mathrm{s}$ to $5.4 \mathrm{~m} / \mathrm{s}$ (Yáñez-Arancibia et al. 2009). Monreal-Gómez et al. (1992) documented that the water circulation and hydrodynamic condition of the Gulf of Mexico are controlled by loop currents and anticyclonic rings. There are "northers" associated with weather conditions of a short time scale (2-3 days) with highpressure system that originates frequently in the Rocky Mountains of the United States and travels from high latitudes to the Gulf of Mexico.

\section{Materials and methods \\ 3.1 Granulometry}

Twenty sediment samples from the Barra del Tordo beach and 20 from the Tesoro beach were air-dried and sieved by a Ro-Tap sieve Shaker using American Standard Test Materials sieves from +7 to +270 mesh sizes with $0.50 \phi$ interval for $40 \mathrm{~min}$ ( $\phi$ being a grade-scale that is inverse of the grain diameter; Wentworth 1922). Cumulative curves were constructed and used to calculate the statistical grain-size parameters (mean size and sorting values) by applying the equations of Folk and Ward (1957). The Ro-Tap sieve Shaker is located at the Sedimentology Laboratory, Instituto de Ciencias del Mar y Limnología (ICML), Universidad Nacional Autónoma de México (UNAM), Mexico City.

\subsection{SEM-EDS}

Sand grain composition was obtained randomly by wave dispersive analyses (WDS) using a JEOL JXA-8900R electron microprobe housed in the Institute of Geophysics, UNAM, Mexico City. Peak counting times were $40 \mathrm{~s}$ for each element, except for $\mathrm{Na}$ and $\mathrm{K}$ with $10 \mathrm{~s}$.

\subsection{Thin-section petrography}

Twenty thin-sections (10 from Tesoro beach and 10 from Tordo beach) were prepared following a common procedure. The modal component was studied based on the Gazzi-Dickinson point counting methodology (Gazzi 1966; Dickinson 1970). Combined organic and inorganic stains specific for iron-rich calcite (Katz and Friedman 1965) were adopted to identify the mineralogical variations.

\subsection{Sediment composition}

Twenty bulk sediment samples (10 from Tesoro beach and 10 from Tordo beach) were powdered by an agate 


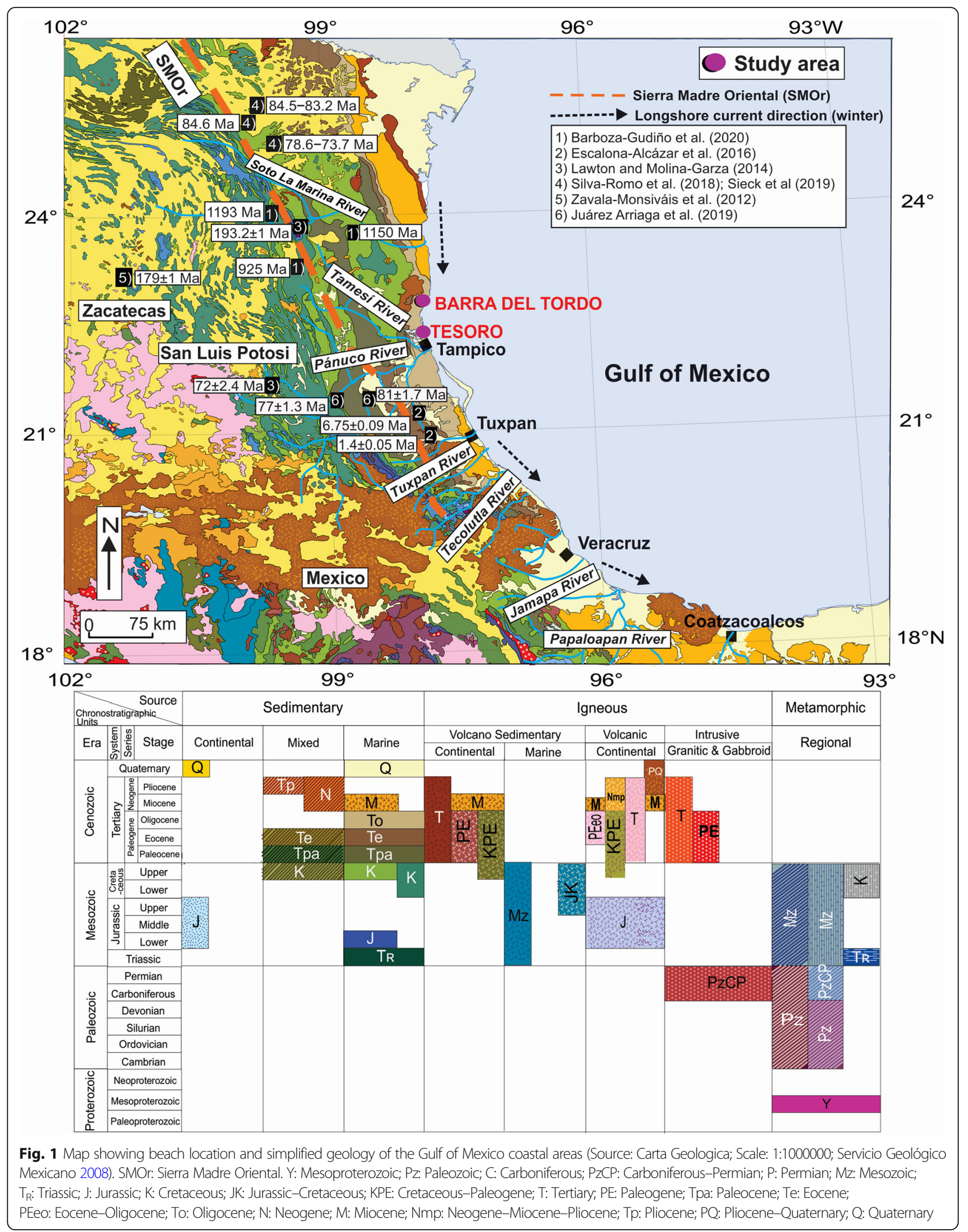


mortar, and the major element concentrations were determined using a Thermo Scientific Niton FXL 950 X-Ray Fluorescence (XRF) analyzer (Balaram 2021). Accuracy of the major element analysis was monitored by an International Standard Gabbro JGB1 (GSJ). The precision of major element data was better than $5 \%$. Loss on ignition was obtained by weighing after combusting $1 \mathrm{~h}$ at $1000^{\circ} \mathrm{C}$. Similarly, the trace and REE concentrations for 20 sediment samples were determined by a VG Elemental PQII Plus ICP-MS and the operation procedure was similar as the detailed in Jarvis (1988). For data calibration, the United States Geological Survey Standard BCR-2 (Basalt, Columbia River) was used. In general, the analytical precision was less than $5 \%$. Eu and Ce anomalies are calculated as $\mathrm{Eu} / \mathrm{Eu}^{\prime \prime}=\mathrm{Eu}_{\mathrm{CN}} /\left[\left(\mathrm{Sm}_{\mathrm{CN}}\right) \cdot\left(\mathrm{Gd}_{\mathrm{CN}}\right)\right]^{1 / 2}$ and $\mathrm{Ce} / \mathrm{Ce}{ }^{\prime \prime}=\mathrm{Ce}_{\mathrm{CN}} /$ $\left[\left(\mathrm{La}_{\mathrm{CN}}\right) \cdot\left(\mathrm{Pr}_{\mathrm{CN}}\right)\right]^{1 / 2}$, respectively (CN means chondritenormalized values from Taylor and McLennan 1985).

\subsection{Detrital zircon $\mathrm{U}-\mathrm{Pb}$ dating}

Four hundred zircon grains were analyzed for $\mathrm{U}-\mathrm{Pb}$ ages, 200 from Tordo beach (sample numbers PBT1 and PBT13) and 200 from Tesoro beach (sample numbers PT1 and PT19). The detrital zircon grains were handpicked under a binocular microscope and then mounted in an epoxy disc. The cathodoluminescence images of detrital zircon grains from the Barra del Tordo and Tesoro beach sediments analyzed in this study are provided in Additional file 1 (Supplementary Information 1 and 2, respectively). Zircon $\mathrm{U}-\mathrm{Pb}$ geochronology was performed by a Laser Ablation Inductively Coupled Plasma Mass Spectrometry (LA-ICPMS) at the Laboratorio de Estudios Isotópicos (LEI), Centro de Geociencias, UNAM.

The laser ablation system at LEI consists of a Resonetics M050 workstation, equipped with an LPX 220 excimer laser and an S-155 two-volume cell (Müller et al. 2009; Paton et al. 2010; Petrus and Kamber 2012). The laser workstation is connected to either a Thermo ICap Qcquadrupole ICPMS or a Thermo Neptune Plus multi-collector ICPMS. A "squid" signal homogenizer is used right after the ablation cell before the ablated material enters the plasma. $350 \mathrm{ml}$ of $\mathrm{He}$ is used as carrier gas, mixed downstream with $4.5 \mathrm{ml}$ of $\mathrm{N}_{2}$. A frequency of $5 \mathrm{~Hz}$ was employed, with a fluence of $6 \mathrm{~J} / \mathrm{cm}^{2}$.

The background average was subtracted from the net intensity measured for each isotope. The acquisition involved an alternation of 2 analyses of Plešovice reference zircon ( 337 Ma, Sláma et al. 2008), NIST 610 standard glasses and 5 unknown zircons, using standardunknown bracketing method to allow downhole fractionation corrections to be performed with an inhouse developed software (Solari et al. 2010). Precision on measured ratios of ${ }^{207} \mathrm{~Pb} /{ }^{206} \mathrm{~Pb},{ }^{206} \mathrm{~Pb} /{ }^{238} \mathrm{U}$, and ${ }^{208} \mathrm{~Pb} /{ }^{232} \mathrm{Th}$ was $\sim 0.7 \%$ with $1 \sigma$ relative standard deviation. Replicate analyses of the Plešovice zircon indicate an external reproducibility of $0.8 \%, 0.7 \%$, and $1.6 \%$ on the measured ${ }^{207} \mathrm{~Pb} /{ }^{206} \mathrm{~Pb},{ }^{206} \mathrm{~Pb} /{ }^{238} \mathrm{U}$ and ${ }^{208} \mathrm{~Pb} /{ }^{232} \mathrm{Th}$ ratios, respectively. These errors are quadratically included in the quoted uncertainties for individual analyses of the analyzed zircons. Concordia, probability density plots and cumulative proportion curves were generated from the corrected ${ }^{207} \mathrm{~Pb} /{ }^{206} \mathrm{~Pb}$ ratios and the integrated concordant and discordant ages through ISOPLOT 3.70 Software (Ludwig 2003). The Tuff-Zirc algorithm combined in the same software was used to calculate the mean ${ }^{206} \mathrm{~Pb} /{ }^{238} \mathrm{U}$ ages and their errors, as well as to filter outliers, which are preferred for grains younger than $1000 \mathrm{Ma}$ (Ludwig 1998; Ludwig 2003). For grains with ages of $<1000 \mathrm{Ma}$, the analysis was considered concordant if the ${ }^{206} \mathrm{~Pb} /{ }^{238} \mathrm{U}$ and ${ }^{207} \mathrm{~Pb} /{ }^{235} \mathrm{U}$ ages differed by less than $10 \%$. For the grains with ages $>1000 \mathrm{Ma}$, the same test was carried out considering ${ }^{206} \mathrm{~Pb} /{ }^{238} \mathrm{U}$ and ${ }^{207} \mathrm{~Pb} /{ }^{206} \mathrm{~Pb}$ ages.

\section{Results}

\subsection{Bulk sediment}

\subsubsection{Textural parameters}

The textural parameters for the Barra del Tordo and Tesoro beach sediments are listed in Additional file 2 (Supplementary Information 3). The Tordo beach sediments are predominately medium-grained, moderately sorted, near symmetrical, and very leptokurtic. On the other hand, Tesoro beach sediments are predominantly fine-grained, moderately sorted, near symmetrical, and very leptokurtic.

\subsubsection{Mineralogy}

The minerals detected by SEM-EDS are mainly quartz, ilmenite, magnetite, titanite, zircon, and anorthite in both the Tordo and Tesoro beach sediments (Fig. 2). In addition, the thin section study reveals some accessory minerals, such as amphibole, biotite, chlorite, epidote, feldspar, plagioclase, pyroxene, monocrystalline quartz, lithic volcanic, lithic sediments, and bioclast in the Tordo beach sediments (Fig. 3a-f), and biotite, chlorite, plagioclase, and lithic volcanic in the Tesoro beach sediments (Fig. 3g-1).

\subsubsection{Geochemistry}

The major element concentrations of Tordo and Tesoro beach sediments are reported in the Supplementary Information 4 and their UCC-normalized patterns are showed in Fig. 4a. $\mathrm{SiO}_{2}$ content is $>73$ wt.\% in Tordo and Tesoro beach sediments, which varies between 73.2-91.4 wt.\% and 82.7-84.1 wt.\% respectively. The $\mathrm{SiO}_{2}$ content shows negative correlation with $\mathrm{TiO}_{2}$, $\mathrm{Al}_{2} \mathrm{O}_{3}, \mathrm{Fe}_{2} \mathrm{O}_{3}, \mathrm{MgO}, \mathrm{MnO}$, and $\mathrm{CaO}$ for Tordo beach sediments $(\mathrm{r}=-0.99,-0.19,-0.99,-0.98,-0.99$, and 0.63 , respectively; $\mathrm{n}=10$ ) and for Tesoro beach 

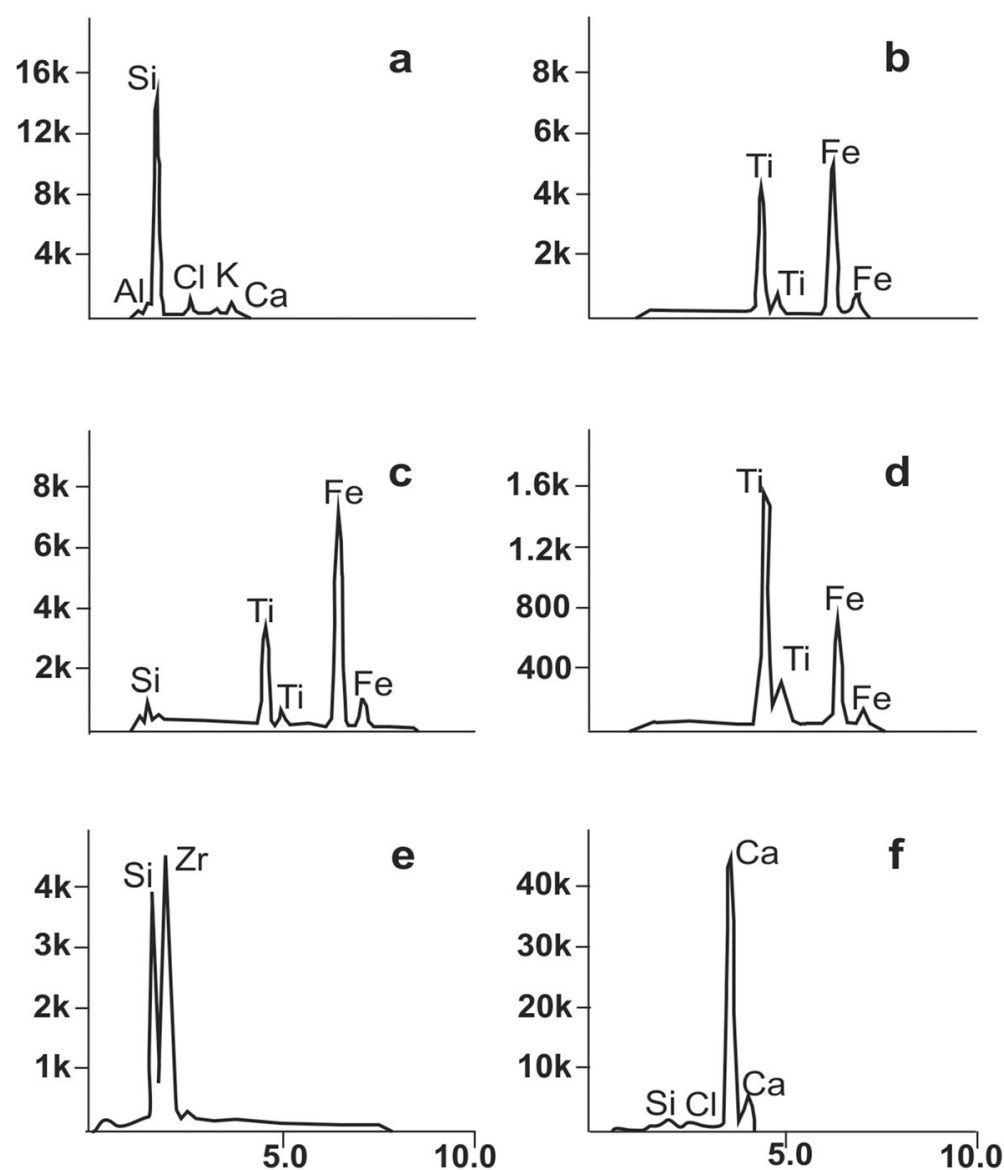

Fig. 2 SEM-EDS spectrum for the a-c Barra del Tordo and $\mathbf{d}-\mathbf{f}$ Tesoro beach sediments, northwestern Gulf of Mexico. a Quartz spectrum; b IImenite spectrum; c Magnetite spectrum; d Titanite spectrum; e Zircon spectrum; and f Anorthite spectrum

sediments $(\mathrm{r}=-0.19,-0.17,-0.06,-0.37,-0.43$, and 0.52 , respectively; $\mathrm{n}=10)$. Significantly positive correlations between $\mathrm{TiO}_{2}$ vs. $\mathrm{P}_{2} \mathrm{O}_{5}(\mathrm{r}=0.74, \mathrm{n}=10)$ and $\mathrm{Al}_{2} \mathrm{O}_{3}$ vs. $\mathrm{K}_{2} \mathrm{O}(\mathrm{r}=0.72, \mathrm{n}=10)$ are observed for the Tesoro beach sediments. The differences in major element concentrations between the Tordo and Tesoro beach sediments are probably related with grain size variations (Mean grain size $=2.26 \pm 0.29$ and $3.11 \pm 0.11$, respectively; Supplementary Information 3). In Tordo beach sediments, compared to the characteristics of UCC, an enrichment of $\mathrm{SiO}_{2}$ content is observed, whereas $\mathrm{Al}_{2} \mathrm{O}_{3}, \mathrm{MgO}, \mathrm{CaO}, \mathrm{Na}_{2} \mathrm{O}, \mathrm{K}_{2} \mathrm{O}$ and $\mathrm{P}_{2} \mathrm{O}_{5}$ are depleted (Fig. 4a). However, in Tesoro beach sediments, UCCnormalized major element patterns are basically different, except for the enrichment in $\mathrm{SiO}_{2}$ content relative to UCC (Fig. 4a).

The trace element concentrations of the Tordo and Tesoro beach sediments are reported in Additional file 2 (Supplementary Information 5). On the UCCnormalized trace element plot (Fig. 4b), the trace element concentrations of both beach sediments are depleted relative to the UCC except $\mathrm{Cu}$ content. Correlations between $\mathrm{SiO}_{2}$ and $\mathrm{V}, \mathrm{Sr}, \mathrm{Rb}, \mathrm{Th}, \mathrm{Sc}, \mathrm{Zr}$, and REE contents are not significant in both Tordo $(r=-0.99,-0.16$, $0.25,-0.96,-0.99,-0.99$, and -0.97 , respectively; $\mathrm{n}=10$ ) and Tesoro beach sediments $(\mathrm{r}=0.13,-0.33,-0.09$, $0.23,-0.38,0.098$, and -0.03 , respectively; $\mathrm{n}=10$ ). While $\mathrm{Al}_{2} \mathrm{O}_{3}$ is negatively correlated with $\mathrm{Co}, \mathrm{Ni}$, and $\mathrm{Zr}$ in the samples from Tordo $(r=-0.218,-0.22$, and -0.21 , respectively) and Tesoro $(r=-0.49,-0.31$, and -0.58 , respectively) beaches. Positive correlations can be observed between $\mathrm{Cu}$ and $\mathrm{Ca}, \mathrm{Sr}, \mathrm{Rb}, \mathrm{Ba}$ and $\mathrm{Zn}(\mathrm{r}=0.63,0.68,0.70$, 0.71 , and $0.91, n=20$ ) in the samples from the Tordo and Tesoro beaches.

The REE contents in the Tordo and Tesoro beach sediments are reported in Additional file 2 (Supplementary Information 5). The chondrite-normalized REE patterns of bulk sediments are shown in Fig. 4c, and are more fractionated in the Tordo relative to the Tesoro beach sediments. The REE patterns are with distinct negative europium $\left(\mathrm{Eu} / \mathrm{Eu}^{\prime \prime}\right)$ anomaly. The $\mathrm{Eu} / \mathrm{Eu}^{\prime \prime}$ ratios for Tordo and Tesoro beach sediments range between $0.50-0.80$ and $\sim 0.56-0.68$ respectively. A significantly positive correlation is observed for $\Sigma$ REE against $\mathrm{TiO}_{2}$, 

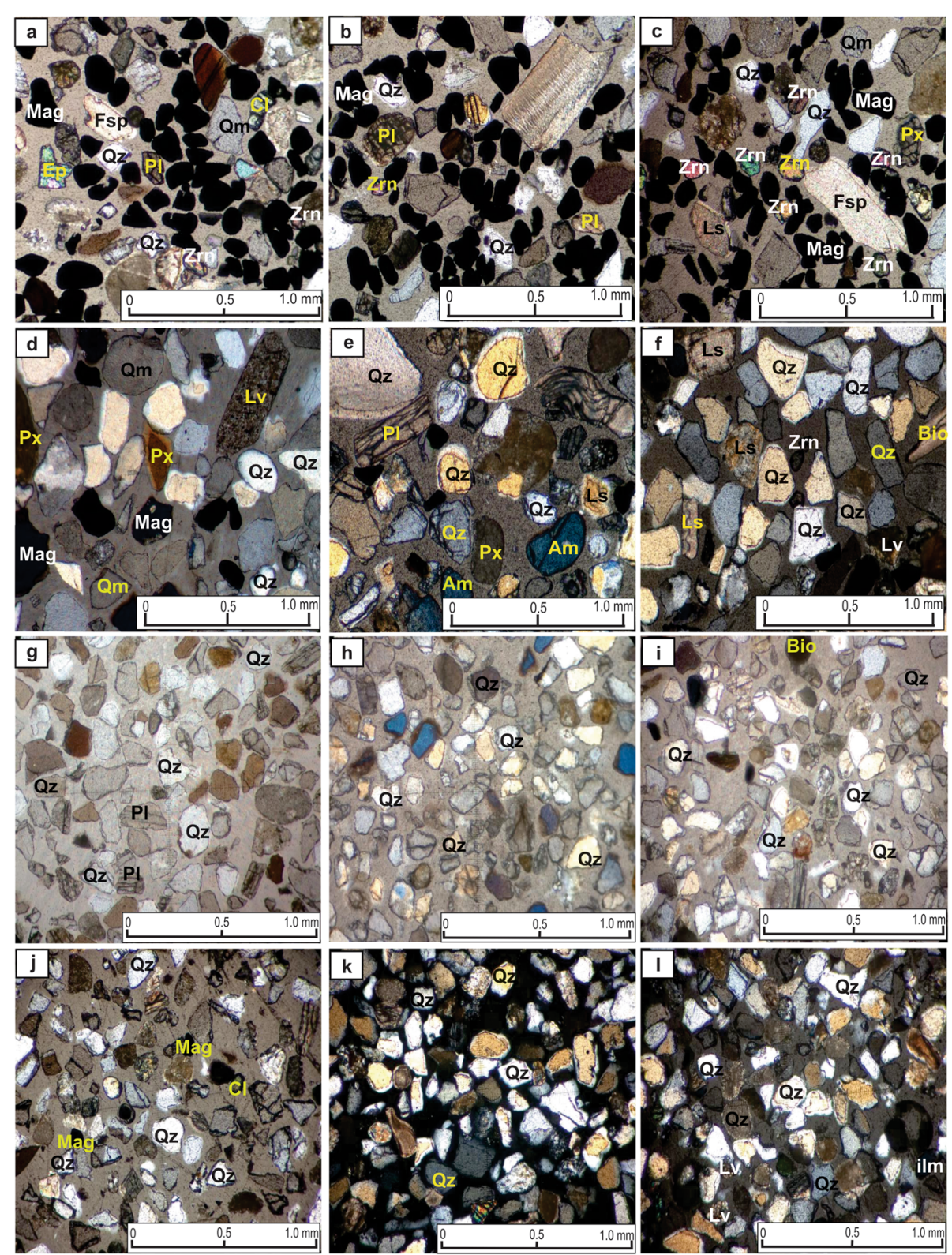

Fig. 3 Thin-section photomicrographs for the a-f Bara del Tordo and $\mathbf{g}-\mathbf{I}$ Tesoro beach sediments, northwestern Gulf of Mexico. Am: Amphibole; Bio: Biotite; Cl: Chlorite; Ep: Epidote; Fsp: Feldspar; Ilm: Ilmenite; Ls: Lithic sediments; Lv: Lithic volcanic; Mag: Magnetite; Pl: Plagioclase; Px: Pyroxene; Qm: Monocrystalline quartz; Qz: Quartz; Zrn: Zircon

$\mathrm{Fe}_{2} \mathrm{O}_{3}, \mathrm{MnO}, \mathrm{MgO}$, Th, and $\mathrm{Zr}$ in Tordo $(\mathrm{r}=0.96,0.98$, $0.98,0.98,0.99$, and 0.99 , respectively) and Tesoro $(\mathrm{r}=$ $0.52,0.52,0.60,0.59,0.51$, and 0.72 , respectively) beach sediments.

\subsection{Detrital zircon U-Pb geochronology \\ 4.2.1 Barra del Tordo beach}

The zircon $\mathrm{U}-\mathrm{Pb}$ ages analyzed for Tordo beach sediments (PBT1 and PBT13) are reported in Additional file 2 (Supplementary Information 6) and their average age groups are listed in Table 1. Among 200 analyses, 193 zircon grains yielded concordant ages (Fig. 5a and c). The youngest concordant zircon age is $1.2 \pm 0.1 \mathrm{Ma}$, and the oldest is $2094 \pm 45 \mathrm{Ma}$. The spectrums of $\mathrm{U}-\mathrm{Pb}$ ages of samples PBT1 and PBT13 are similar including age populations of the Proterozoic (2094-595.8 Ma and 1732-632.2 Ma, number of zircons $=34$ and $n=21$, respectively), the Paleozoic (455.7-262 Ma and 481.2$252.5 \mathrm{Ma}, \mathrm{n}=5$ and $\mathrm{n}=8$, respectively), the Mesozoic (177.7-70.3 Ma and 243.8-68.9 Ma, $\mathrm{n}=24$ and $\mathrm{n}=28$, respectively), and, the Cenozoic (59.5-1.2 Ma and 58.21.2 Ma, $n=33$ and $n=40$, respectively). The probability 

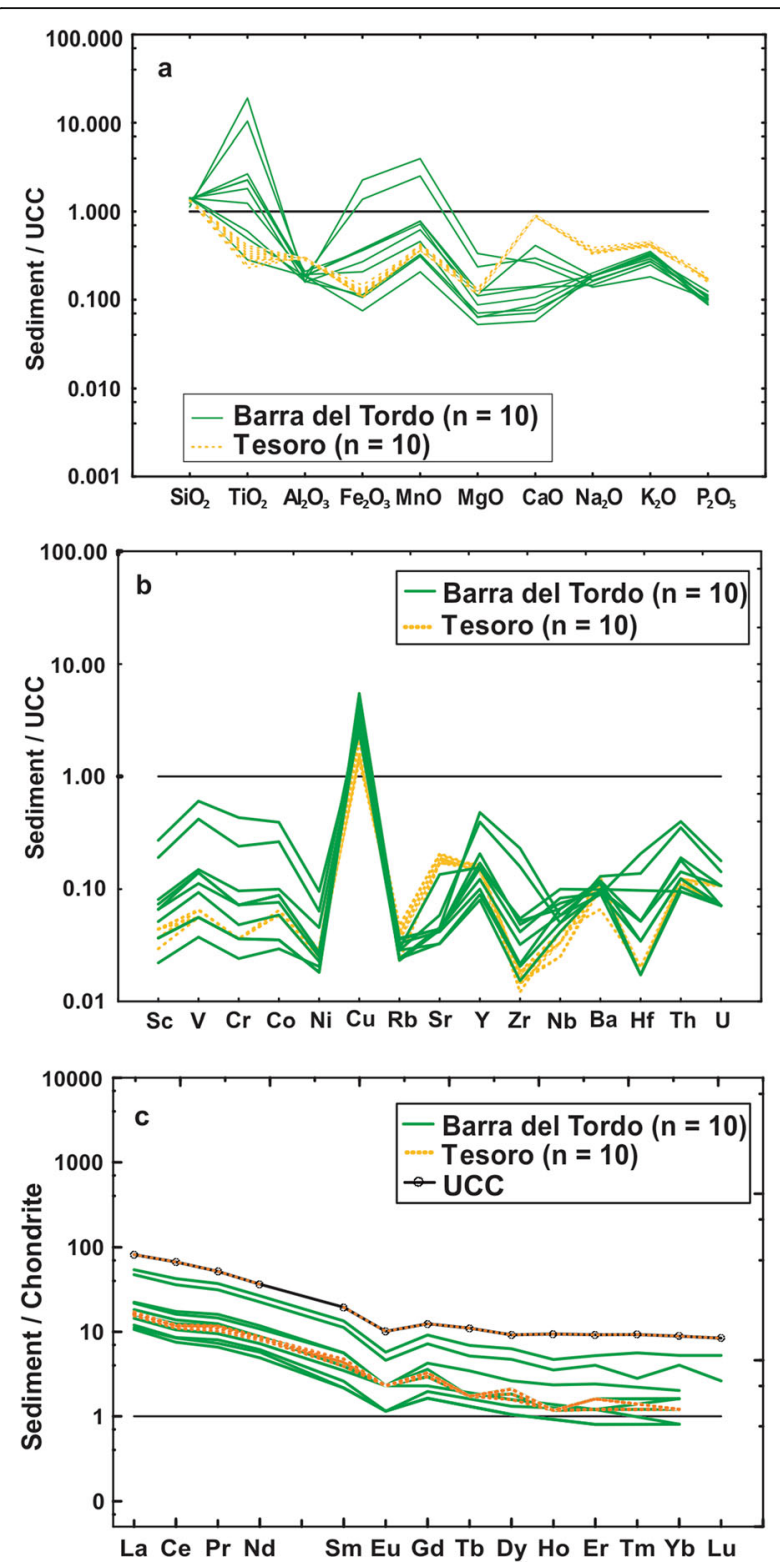

Fig. 4 a Upper continental crust (UCC)-normalized diagram for major element concentrations of the Barra del Tordo and Tesoro beach sediments; b UCC-normalized diagram for trace element concentrations of the Barra del Tordo and Tesoro beach sediments; c Chondrite-normalized REE patterns for the Barra del Tordo and Tesoro beach sediments. The UCC and chondrite values are from Taylor and McLennan (1985)

density plots show three major peaks (Fig. $5 \mathrm{~b}$ and d), which correspond to the Proterozoic, Mesozoic, and Cenozoic.

\subsubsection{Tesoro beach}

The zircon $\mathrm{U}-\mathrm{Pb}$ ages obtained from two samples (PT1 and PT19) are listed in Additional file 2 (Supplementary Information 7). Among 200 analyses, 188 zircons yielded concordant ages (Fig. 6a and c). The probability
Table 1 Detrital zircon U-Pb age groups of the Barra del Tordo and Tesoro beach sediments, northwestern Gulf of Mexico (refer Additional file 2 for complete data)

\begin{tabular}{lll}
\hline $\begin{array}{ll}\text { Barra del Tordo beach sediments } \\
\text { Age population }\end{array}$ & \multicolumn{2}{c}{ Number of zircon grains } \\
& PBT1 & PBT13 \\
Proterozoic (2094-595.8 Ma) & 34 & 21 \\
Paleozoic (481.2-252.5 Ma) & 5 & 8 \\
Mesozoic (243.8-68.9 Ma) & 24 & 28 \\
Cenozoic (59.5-1.2 Ma) & 33 & 40 \\
Total & 96 & 97
\end{tabular}

Tesoro beach sediments

Age population

Number of zircon grains

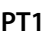

PT19

Proterozoic (2593-560.4 Ma)

Paleozoic (540-254.9 Ma)

Mesozoic (249.3-71 Ma)

$25 \quad 30$

$10 \quad 10$

Cenozoic (69.9-23.3 Ma)

Total

$30 \quad 28$

$27-28$

$92 \quad 96$

density plots for samples PT1 and PT19 are shown in Fig. $6 \mathrm{~b}$ and $\mathrm{d}$. The youngest concordant zircon age is $23.3 \pm 0.8 \mathrm{Ma}$, and the oldest is $2593 \pm 21 \mathrm{Ma}$. Four zircon $\mathrm{U}-\mathrm{Pb}$ age populations obtained from samples PT1 and PT19 are the Proterozoic (2593-560.4 Ma and 2039-669 Ma; $\mathrm{n}=25$ and $\mathrm{n}=30$, respectively), the Paleozoic (540-254.9 Ma and 477.5-268.5 Ma, $\mathrm{n}=10$ and $n=10$, respectively), the Mesozoic (249.3-78.4 Ma and 244-71 Ma; $n=30$ and $n=28$, respectively), and the Cenozoic (64.3-25.7 Ma and 65.9-23.3 Ma; $\mathrm{n}=27$ and $\mathrm{n}=28$, respectively).

\section{Discussion}

\subsection{Elemental variations}

A negative correlation of $\mathrm{SiO}_{2}$ against major $\left(\mathrm{TiO}_{2}\right.$, $\mathrm{Al}_{2} \mathrm{O}_{3}, \mathrm{Fe}_{2} \mathrm{O}_{3}, \mathrm{MgO}, \mathrm{MnO}, \mathrm{CaO}$, and $\mathrm{P}_{2} \mathrm{O}_{5}$ ) and trace (V, Sr, Rb, Th, Sc, Zr, and IREE) elements in the Barra del Tordo beach sediments indicates that silica is hosted in quartz rather than accessory minerals. Similarly, a negative correlation between $\mathrm{Al}_{2} \mathrm{O}_{3}$ and $\mathrm{Co}, \mathrm{Ni}, \mathrm{Zr}$ for Tordo and Tesoro beach sediments indicates an association of $\mathrm{Al}_{2} \mathrm{O}_{3}$ with accessory minerals rather than aluminosilicates. A positive correlation between $\mathrm{TiO}_{2}$ and $\mathrm{P}_{2} \mathrm{O}_{5}$ in Tordo and Tesoro beach sediments indicates a similar source and their association with accessory minerals. An enrichment in $\mathrm{TiO}_{2}, \mathrm{Fe}_{2} \mathrm{O}_{3}$, and $\mathrm{MnO}$ contents is noted in samples PBT1 and PBT7, indicating their association with magnetite. Similarly, a positive correlation of $\Sigma$ REE versus $\mathrm{TiO}_{2}$, $\mathrm{Fe}_{2} \mathrm{O}_{3}, \mathrm{MnO}, \mathrm{MgO}, \mathrm{Th}$, and $\mathrm{Zr}$ in the Tordo and Tesoro beach sediments is suggestive of the association of REE with accessory minerals. $\mathrm{Cu}$ reveals a positive correlation 

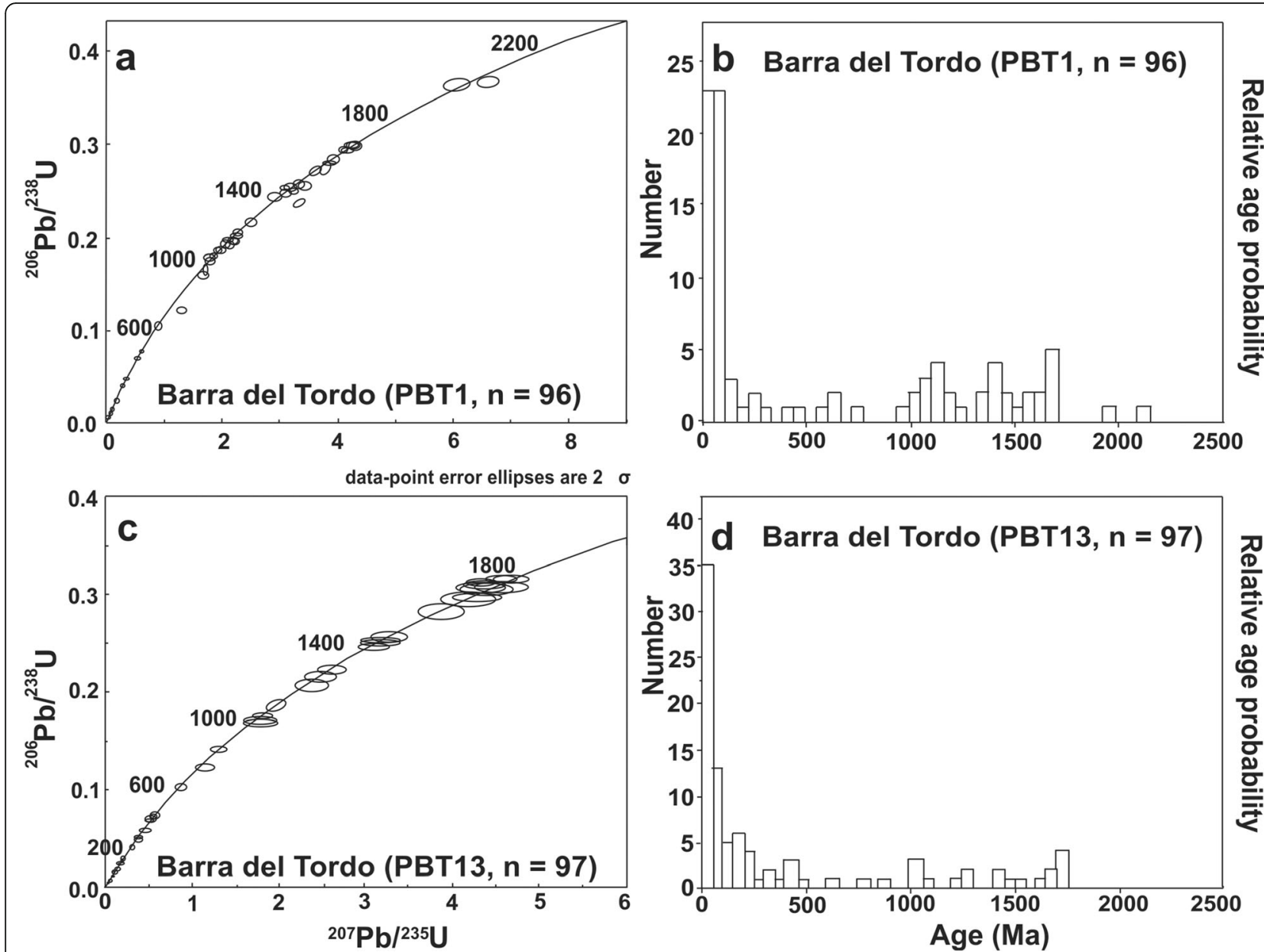

Fig. $5 \mathrm{U}-\mathrm{Pb}$ concordia diagrams and histograms showing the relative age probability distribution of detrital zircon grains from samples PBT1 (a and $\mathbf{b}$ ) and PBT13 (c and $\mathbf{d}$ ) of the Barra del Tordo beach sediments, northwestern Gulf of Mexico. $n=$ Number of zircon grains

against $\mathrm{Ca}, \mathrm{Sr}, \mathrm{Rb}, \mathrm{Ba}$, and $\mathrm{Zn}$ for Tordo and Tesoro beach sediments and indicates the association of these elements with a similar source. The REE fractionation of Tordo beach sediments is probably due to the effect of weathering.

\subsection{Sediment weathering and sorting}

The chemical composition of detrital sediments is highly useful to interpret sediment recycling and intensity of weathering (Devi et al. 2017; Basu 2020; Patra and Shukla 2020; Verlekar and Kotha 2020). In this study, weathering indices like Chemical Index of Alteration (CIA; Nesbitt and Young 1982), Chemical Index of Weathering (CIW; Harnois 1988), and Plagioclase Index of Alteration (PIA; Fedo et al. 1995) are applied to infer the intensity of weathering (Supplementary Information 4). The CIA, CIW, and PIA values in the Tordo and Tesoro beach sediments vary between $\sim 44.6-57.5$, $47.5-74.5$, and $\sim 41.9-63.8$ respectively, indicating moderate to high intensity of weathering in the source area (Supplementary Information 4).

Hydraulic sorting of sediments can be evaluated by the Index of Compositional Variability (ICV), which decreases when weathering increases (Cox et al. 1995). The ICV values of Tordo beach sediments vary from 0.95 to 2.41 , except for two samples PBT1 and PBT7, which show higher values relative to other samples ( 9.4 and 5.2, respectively). ICV values of Tesoro beach sediments range between 1.61 and 1.78 (Supplementary Information 4). According to Cox et al. (1995), ICV > 1 indicates littleweathered detrital minerals like feldspar, and ICV $<1$ represents fine-grained sediments like clay. In general, ICV values in Tesoro and Tordo beach sediments are larger than 1 , indicating the dominance of detrital minerals.

\subsection{Provenance}

\subsubsection{Geochemistry}

To infer the provenance of the Barra del Tordo and Tesoro beach sediments, we employed a provenance 

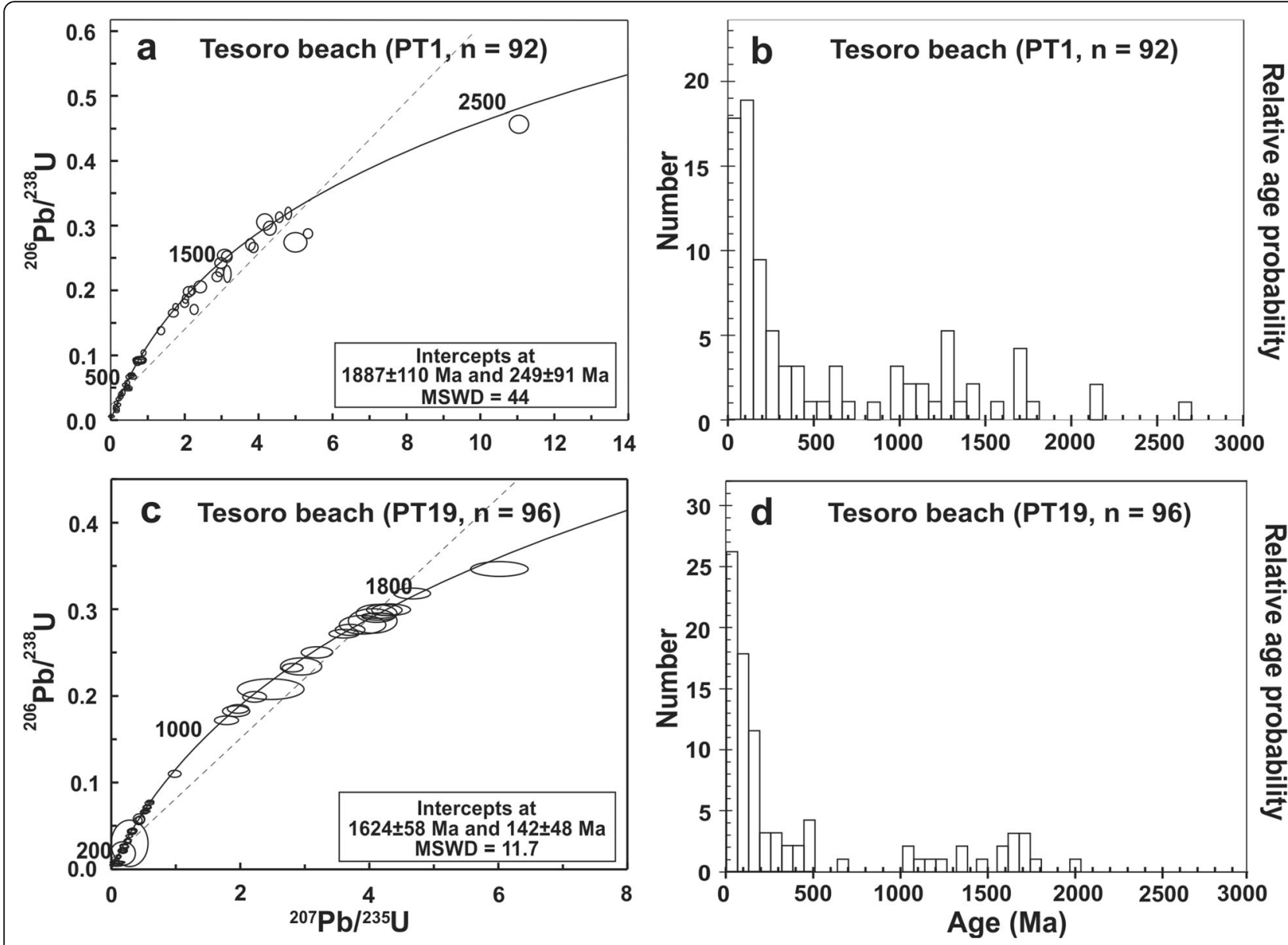

Fig. $6 \mathrm{U}-\mathrm{Pb}$ concordia diagrams and histograms showing the relative age probability distribution of detrital zircon grains from samples PT1 (a and $\mathbf{b}$ ) and PT19 (c and $\mathbf{d}$ ) of the Tesoro beach sediments, northwestern Gulf of Mexico. $n=$ Number of zircon grains

discrimination diagram based on the major oxides (Roser and Korsch 1988), which is frequently used in various studies (e.g. Tawfik et al. 2018; Bineli et al. 2020; Madhavaraju et al. 2020; Mustafa and Tobia 2020). On this plot, the samples are clustered in the quartzose sedimentary provenance field (Fig. 7), indicating a recycled quartzose provenance. Besides, the $\mathrm{TiO}_{2} / \mathrm{Zr}$ ratio in detrital sediments is one of the best indicators on source rock types (Girty et al. 1996). $\mathrm{TiO}_{2} / \mathrm{Zr}$ ratio values are higher in mafic igneous $(>195)$ rocks than in intermediate $(\sim 55-195)$ and felsic $(<55)$ igneous rocks. The $\mathrm{TiO}_{2} / \mathrm{Zr}$ ratios are very low in the Tordo and Tesoro beach sediments $(\sim 0.05-0.22$ and $\sim 0.04-0.09$, respectively), indicating their derivation from felsic source rocks.

Trace element concentrations of sediments, particularly immobile elements like $\mathrm{La}, \mathrm{Sc}, \mathrm{Co}, \mathrm{Cr}$, Th, and REE are helpful to predict the nature of source rocks, due to a compositional difference between silicic and mafic rocks (e.g. Anaya-Gregorio et al. 2018; Cullers 2000). Hence, the immobile elements and their elemental ratios are utilized in various studies to differentiate source rocks (e.g. Damian et al. 2019; Hossain 2019; Tobia and Shangola 2019; Patra and Shukla 2020; Ekoa Bessa et al. 2021). $\mathrm{La} / \mathrm{Sc}, \mathrm{La} / \mathrm{Co}, \mathrm{Th} / \mathrm{Sc}$, and $\mathrm{Cr} / \mathrm{Th}$ ratios in the Tordo and Tesoro beach sediments are compared with sediments derived from felsic and mafic sources, as well as with average UCC values (Supplementary Information 8). This comparative study reveals that these sediments were likely derived from felsic source rocks. Furthermore, the relative chondrite-normalized REE pattern and the Eu anomaly have also been used to infer the source of clastic sediments (e.g. Cullers 2000; Hernández-Hinojosa et al. 2018; Kettanah et al. 2021; Madhavaraju et al. 2021). The REE patterns of the Tordo and Tesoro beach sediments are both with a significantly negative $\mathrm{Eu}$ anomaly, indicating felsic igneous rocks as their sources (Fig. 4c).

\subsubsection{Geochronological evidence}

Three major zircon $\mathrm{U}-\mathrm{Pb}$ age populations are identified in the Barra del Tordo and Tesoro beach sediments 


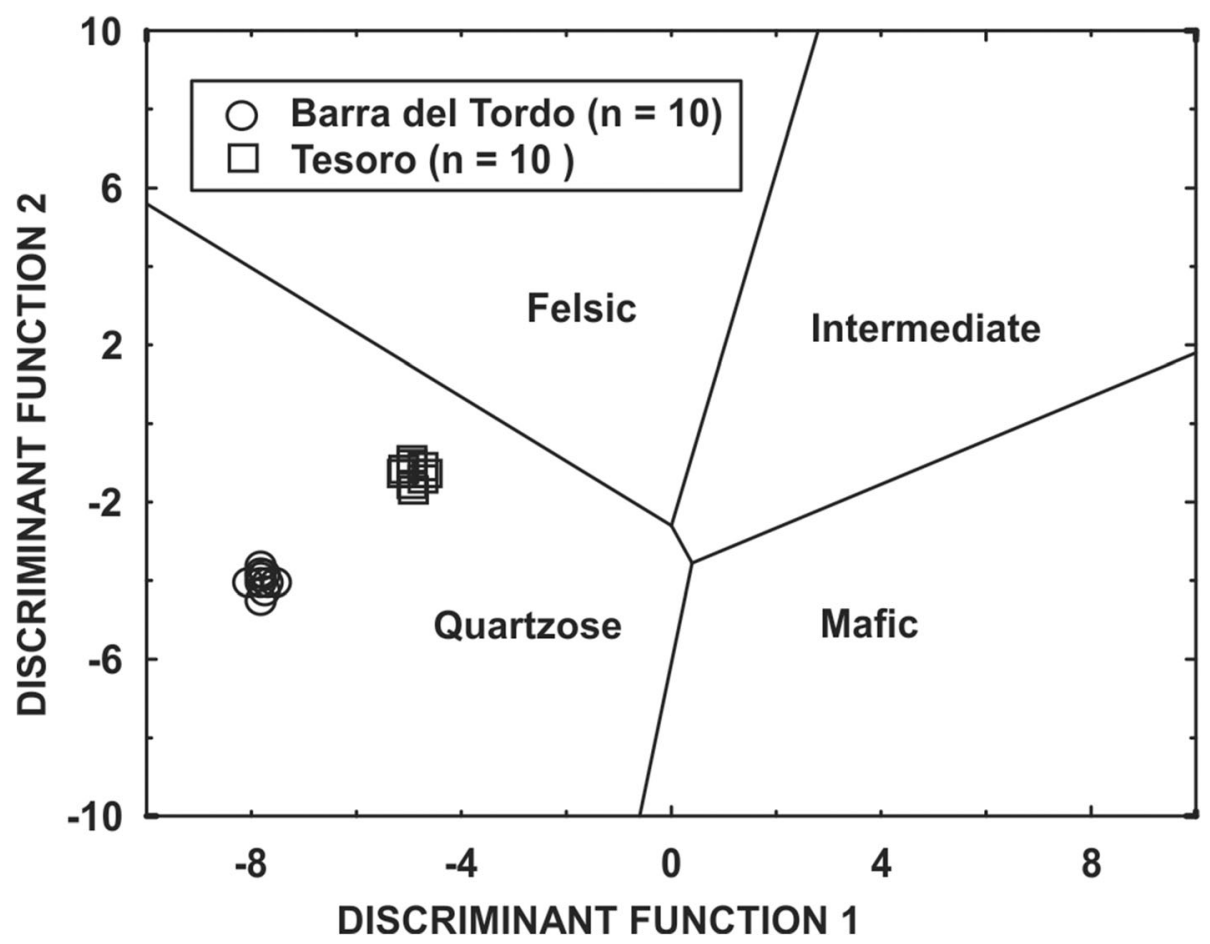

Fig. 7 Provenance discriminant function (DF) diagram for the Barra del Tordo and Tesoro beach sediments (modified after Roser and Korsch 1988). DF $1=\left(-1.773 \cdot \mathrm{TiO}_{2}\right)+\left(0.607 \cdot \mathrm{Al}_{2} \mathrm{O}_{3}\right)+\left(0.760 \cdot \mathrm{Fe}_{2} \mathrm{O}_{3}\right)+(-1.500 \cdot \mathrm{MgO})+(0.616 \cdot \mathrm{CaO})+\left(0.509 \cdot \mathrm{Na}_{2} \mathrm{O}\right)+\left(-1.224 \cdot \mathrm{K}_{2} \mathrm{O}\right)+(-9.090)$; DF $2=\left(0.445 \cdot \mathrm{TiO}_{2}\right)+\left(0.070 \cdot \mathrm{Al}_{2} \mathrm{O}_{3}\right)+\left(-0.250 \cdot \mathrm{Fe}_{2} \mathrm{O}_{3}\right)+(-1.142 \cdot \mathrm{MgO})+(0.438 \cdot \mathrm{CaO})+\left(1.475 \cdot \mathrm{Na}_{2} \mathrm{O}\right)+\left(1.426 \cdot \mathrm{K}_{2} \mathrm{O}\right)+(-6.861)$

(Table 1; Fig. 8), i.e., (1) Proterozoic (2094-595.8 Ma and 2593-560.4 Ma respectively); (2) Mesozoic (243.8$68.9 \mathrm{Ma}$ and 249.3-71 Ma respectively); and (3) Cenozoic (59.5-1.2 Ma and 65.9-23.3 Ma, respectively). Detrital zircon $\mathrm{U}-\mathrm{Pb}$ dating ages of this study are compared with the detrital zircon ages from potential source terranes of northwestern Mexico (Fig. 8).

The Proterozoic age population in this study is similar to zircon $\mathrm{U}-\mathrm{Pb}$ ages reported from the Sierra Madre Oriental, Tamaulipas State, which represent the Grenvillian ( 1250-920 Ma) and the Pan-African orogen period ( 730-530 Ma). Another likely source for the Proterozoic zircons of the Tordo and Tesoro beaches is the Oaxacan Complex, which contains extensive outcrops of the Grenvillian basement rocks (Barboza-Gudiño et al. 2010; Solari et al. 2014). Weber et al. (2010) reported the zircon U-Pb ages from the Oaxacan Complex, which vary from 1500 Ma to $950 \mathrm{Ma}$. Recently, Vega-Granillo et al. (2020) assigned a Proterozoic age for the zircons dated from the northern part of the Oaxacan Complex ( 1300-950 Ma). Furthermore, Escalona-Alcázar et al. (2016) and BarbozaGudiño et al. (2020) reported the Proterozoic age zircons in the Mesa Central Province and they inferred that the Oaxacan Complex is the potential source terrane which supplied Proterozoic zircons to the Mesa Central. Hence, here it is inferred that the potential source terranes, which contributed Proterozoic age zircons to the Tordo and
Tesoro beaches, are Sierra Madre Oriental and Oaxacan Complex. Besides, although the numbers of Paleozoic age zircons are both rare in Tordo $(\mathrm{n}=13)$ and Tesoro $(\mathrm{n}=$ 20) beach sediments, we infer that the likely source for theses Paleozoic zircons is the La Joya Formation in the Mesa Central Province (the Huizachal Group; RubioCisneros and Lawton 2011) due to the resemblance of zircon U-Pb ages ( 256-222 Ma; Rubio-Cisneros and Lawton 2011).

The Mesozoic age population representing the likely source terrane, which supplied Mesozoic zircons to the beach areas, is the Mesa Central Province. The Mesa Central Province consists of Zacatecas, Nazas, and La Joya sedimentary formations (Zavala-Monsiváis et al. 2012). Lawton and Molina-Garza (2014) reported zircon age populations of the Zacatecas and Nazas Formations in northeastern Durango, which vary between $\sim 250$ $179 \mathrm{Ma}$ and $\sim 280-200 \mathrm{Ma}$, respectively. In addition, Escalona-Alcázar et al. (2016) reported zircon U-Pb ages analyzed from the conglomerate of Zacatecas Formation in the Eastern Alkaline Province, and inferred the maximum depositional age of $\sim 81 \mathrm{Ma}$. Recently, JuárezArriaga et al. (2019) dated zircons from different sedimentary formations in the Mesa Central Province and reported the following ages: (1) Tezapotla $(84 \pm 0.6 \mathrm{Ma})$, (2) Alamar (79.2 $\pm 1 \mathrm{Ma})$, (3) Jalpan-Conca (78.7 \pm 0.05 $\mathrm{Ma})$, and (4) Agua Zarca $(77.9 \pm 0.5 \mathrm{Ma})$. Based on the 


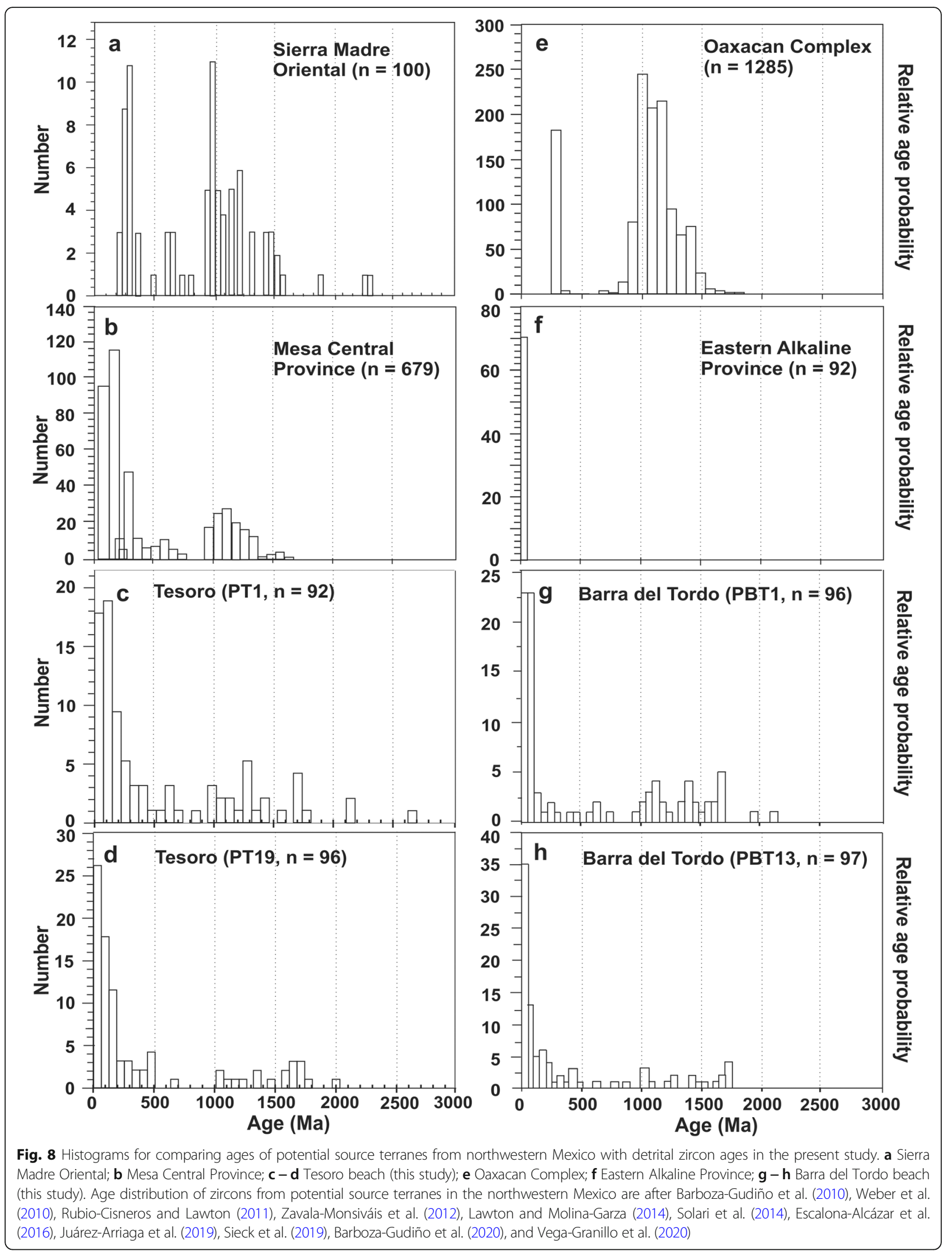


comparison of zircon ages, it is identified that the Mesa Central Province is the source terrane, which supplied Mesozoic zircons to the beach areas.

The Cenozoic age population represents the Eastern Alkaline Province (EAP), which includes various volcanic fields, located in the Gulf of Mexico coastal region (Verma et al. 2020). The zircon ages reported from the EAP volcanic fields range from $8.0 \mathrm{Ma}$ to $2.82 \mathrm{Ma}$. For instance, zircon ages inferred by $\mathrm{K}-\mathrm{Ar}$ and $\mathrm{Ar}-\mathrm{Ar}$ dating are $\leqq 9 \mathrm{Ma}$ in the Tlanchinol succession (7.33-2.82 Ma), Sierra Tantima ( 9.0 Ma), and Alamo volcanic field ( 6.91 Ma) of the EAP (Sieck et al. 2019). Another source for the Cenozoic age zircons is the Mesa Central Province
(MCP), which consists of three tectonomagmatic stages (Sieck et al. 2019). First, a long phase of andesitic to dacitic arc volcanism $(\sim 45-31 \mathrm{Ma})$ connected with the subduction of the Farallon Plate that lasted until EoceneOligocene. Second is an extension-related phase $(\sim 32-25$ $\mathrm{Ma})$ overlapped with the Oligocene to Miocene basin. The third stage corresponds to an Early Miocene $(\sim 23-20$ $\mathrm{Ma}$ ) mafic magmatism that marked the evolution from a continental arc regime to intraplate volcanism. Hence, the similarity in zircon age populations of this study with EAP and MCP reveals that these provinces are the likely sources for the Cenozoic zircons of the Tordo and Tesoro beaches.

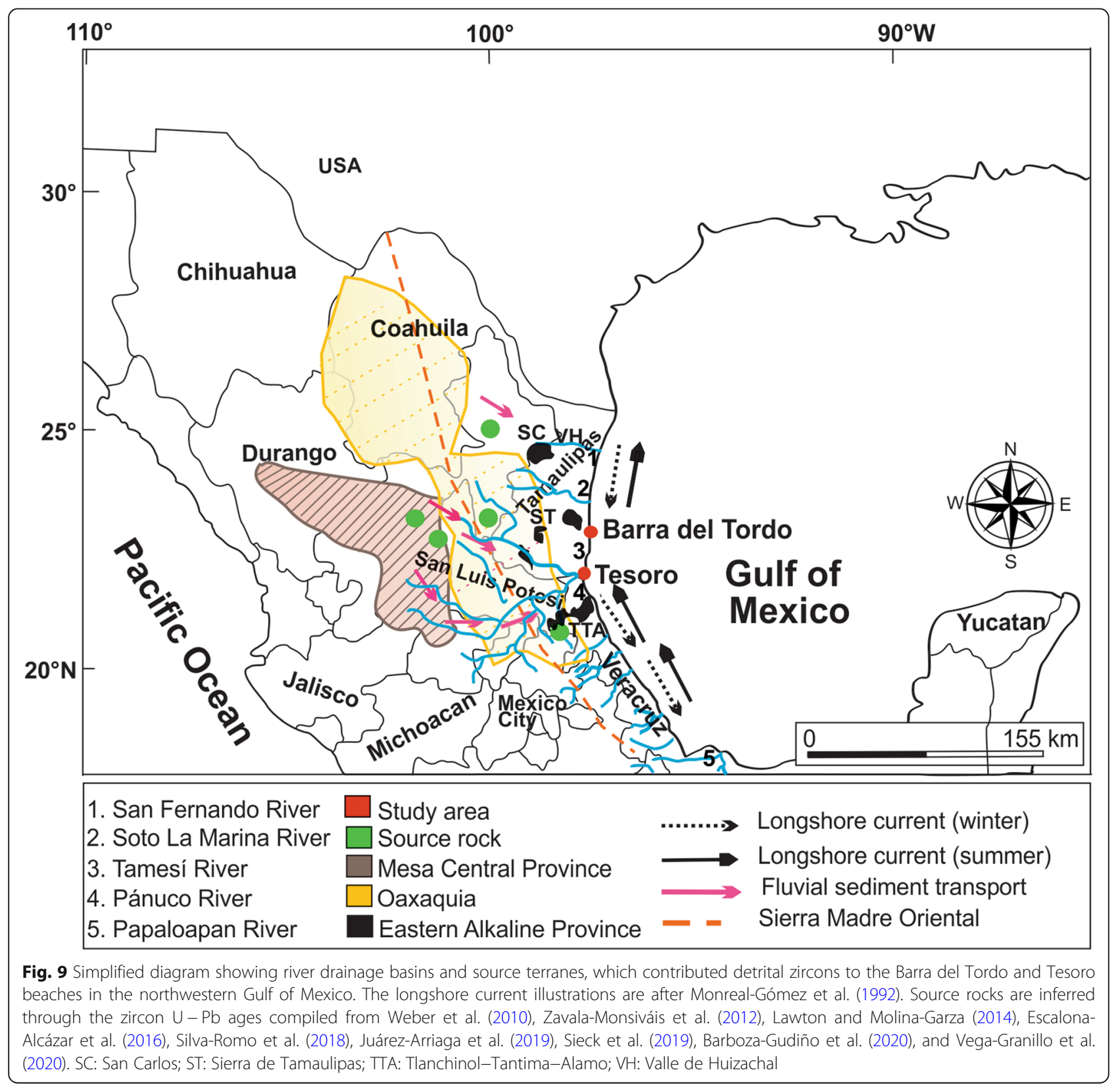


Based on the above discussions, it is assumed that the San Fernando, Soto la Marina, Tamesí, and Pánuco Rivers drained along the Sierra Madre Oriental, Mesa Central Province, and Oaxacan Complex carried sediments to the Barra del Tordo and Tesoro beaches and played an important role in defining the sediment source. The probable sediment transport pathway is briefly illustrated in Fig. 9.

\section{Conclusions}

The mineralogy, sediment composition, and zircon $\mathrm{U}-\mathrm{Pb}$ ages were analyzed to identify the sources, which supplied sediments to the Barra del Tordo and Tesoro beaches in the northwestern Gulf of Mexico. The results of this study reveal that the Barra del Tordo and Tesoro beach sediments are mainly composed of quartz, ilmenite, magnetite, zircon, titanite, and anorthite. The weathering indices like CIA, CIW, and PIA indicate a moderate to high intensity of weathering in the source area. The major element concentrations, trace elemental ratios of $\mathrm{La} / \mathrm{Sc}, \mathrm{La} / \mathrm{Co}, \mathrm{Th} / \mathrm{Sc}$, and $\mathrm{Cr} / \mathrm{Th}$, and REE patterns with prominent negative $\mathrm{Eu}$ anomaly in the Barra del Tordo and Tesoro beach sediments all indicate a felsic provenance.

Zircon $\mathrm{U}-\mathrm{Pb}$ dating for the Barra del Tordo and Tesoro beach sediments suggests three dominant age peaks: Proterozoic ( 2593-560.4 Ma), Mesozoic ( 249.3-68.9 Ma), Cenozoic ( 69.9-1.2 Ma). Differences in U-Pb age populations between the Barra del Tordo and Tesoro beach sediments are not significant, suggesting a similar provenance. It is inferred that the Proterozoic zircons in the beach areas were transported from the Grenvillian igneous suites in the Oaxacan Complex as well as from the Sierra Madre Oriental. The potential suppliers for the Mesozoic and Cenozoic age zircons to the beach areas are the Eastern Alkaline and Mesa Central Provinces, among which the Mesa Central Province is the major contributor of sediments to the Barra del Tordo and Tesoro beach areas. Furthermore, the San Fernando, Soto la Marina, Tamesí, and Pánuco Rivers in the northwestern Gulf of Mexico are interpreted to deliver source sediments to the beach areas, which were subsequently mixed by longshore currents.

\section{Abbreviations}

¿REE: Total rare earth elements; Am: Amphibole; BCR-2: United States Geological Survey Standard Basalt (Columbia River); Bio: Biotite; C: Carboniferous; CIA: Chemical Index of Alteration; CIW: Chemical Index of Weathering; Cl: Chlorite; CMC: Chiapas Massif Complex; CN: Chondritenormalized; CONACyT: Consejo Nacional de Ciencia y Tecnología; DGAPA: Dirección General de Asuntos del Personal Académico; EAP: Eastern Alkaline Province; Ep: Epidote; Fsp: Feldspar; GSJ: Geological Society of Japan; HREE: Heavy rare earth elements; ICML: Instituto de Ciencias del Mar y Limnología; ICPMS: Inductively Coupled Plasma Mass Spectrometry; ICV: Index of Compositional Variability; IIm: IImenite; J: Jurassic; JK: Cretaceous-Jurassic; JGB1: International Standard Gabbro; K: Cretaceous; KPE: Cretaceous-Paleogene; LA-ICPMS: Laser Ablation Inductively Coupled Plasma Mass Spectrometry; LEl: Laboratorio de Estudios Isotópicos; LREE: Light rare earth elements; Ls: Lithic sedimentary; LV: Lithic volcanic; M: Miocene; Mag: Magnetite; MCP: Mesa Central Province; Mz: Mesozoic;
N: Neogene; Nmp: Neogene-Miocene-Pliocene; P: Permian; PAPIIT: Programa de Apoyo a Proyectos de Investigación e Innovación Tecnología; PCML: Posgrado en Ciencias del Mar y Limnologia; PE: Paleogene; PEeo: Eocene-Oligocene; PIA: Plagioclase Index of Alteration; PI: Plagioclase; Px: Pyroxene; Pz: Paleozoic; PzCP: Carboniferous-Permian; PQ: PlioceneQuaternary; Q: Quaternary; Qm: Monocrystalline quartz; Qz: Quartz; R: River; REE: Rare earth element; SC: San Carlos; SEM: Scanning Electron Microscopy; SEM-EDS: Scanning Electron Microscopy - Energy Dispersive X-Ray Spectroscopy; SMOr: Sierra Madre Oriental; ST: Sierra de Tamaulipas; T: Tertiary; Te: Eocene; To: Oligocene; Tp: Pliocene; Tpa: Paleocene; $T_{R}$ : Triassic; TTA: Tlanchinol-Tantima-Alamo; UCC: Upper continental crust; UNAM: Universidad Nacional Autónoma de México; WDS: Wave dispersive analyses; XRF: X-ray fluorescence; Y: Mesoproterozoic; Zrn: Zircon

\section{Supplementary Information}

The online version contains supplementary material available at https://doi. org/10.1186/s42501-021-00101-4.

\begin{abstract}
Additional file 1: Supplementary Information 1. Post-ablation cathodoluminescence images of selected detrital zircons from the Barra del Tordo beach sediments. Supplementary Information 2. Post-ablation cathodoluminescence images of selected detrital zircons from the Tesoro beach sediments.

Additional file 2: Supplementary Information 3. Graphic mean grain size $(\mathrm{Mz})$ and textural parameters for the Barra del Tordo and Tesoro beach sediments, northwestern Gulf of Mexico. Grain size classifications were based on Wentworth (1922) and Folk and Ward (1957). Supplementary Information 4. Major element concentrations (in wt.\%) in the Barra del Tordo and Tesoro beach sediments, northwestern Gulf of Mexico. Supplementary Information 5. Trace and rare earth element concentrations (in ppm) in the Barra del Tordo and Tesoro beach sediments, northwestern Gulf of Mexico. Supplementary Information 6. U-Pb geochronology data for zircons of samples PBT1 and PBT13 analyzed from the Barra del Tordo beach sediments, northwestern Gulf of Mexico. Supplementary Information 7. U-Pb geochronology data for zircons of samples PT1 and PT19 analyzed from the Tesoro beach sediments, northwestern Gulf of Mexico. Supplementary Information 8. Range of trace elemental ratios in the Barra del Tordo and Tesoro beach sediments, compared with ratio range of sediments derived from felsic and mafic rocks, and the Upper Continental Crust.
\end{abstract}

\section{Acknowledgements}

Armstrong-Altrin acknowledges the financial assistance provided by the CONACyT Project (No. A1-S-21287) for zircon grain U-Pb geochronology analysis. We extend our sincere thanks to Patricia Girón García, Carlos LinaresLópez, Laura E. Gómez Lizárraga and Teodoro Hernández Treviño, for XRF, SEM-EDS, SEM, and zircon separation, respectively. We appreciate Dr. Luigi Solari of Centro de Geociencias for U-Pb zircon dating. The textural parameters were analyzed by Eduardo Alfredo Morales, Ricardo Martínez Domínguez, Susana Santiago-Perez, and Arturo Ronquillo Arvizu at the Sedimentology Laboratory, ICML. Mayla A. Ramos-Vázquez is grateful to the Posgrado en Ciencias del Mar y Limnologia (PCML) postgraduate program and to Consejo Nacional de Ciencia y Tecnología (CONACyT) for a doctoral fellowship (No. 595593/308610). We are also grateful to the ICML Institutional Project (No. 616) for providing transportation facilities along the Gulf of Mexico coastal areas. Financial support extended by the Programa de Apoyo a Proyectos de Investigación e Innovación Tecnológica (PAPIIT; Project No. IN107020) is highly acknowledged. We acknowledge the Editor and three anonymous reviewers for their comments, which significantly improved the presentation.

\section{Authors' contributions}

Mayla A. Ramos-Vázquez collected sediment samples along the Barra de Tordo and Tesoro beaches, northwestern Gulf of Mexico, and prepared the samples for SEM and zircon dating studies. John S. Armstrong-Altrin participated in sample collection, examined and interpreted the data. Both authors contributed in writing, reviewing, and editing the manuscript. And both authors read and approved the final paper. 


\section{Funding}

This study was supported by the 1) Consejo Nacional de Ciencia y Tecnologia (CONACyT), Project Number A1-S-21287; 2) Direccíon General de Asuntos del Personal Académico (DGAPA) - Programa de Apoyo a Proyectos de Investigación e Innovación Tecnología (PAPIIT), Project Number IN107020; 3) Instituto de Ciencias del Mar y Limnologia Institutional Fund Number 616.

\section{Availability of data and materials}

All data discussed in this study are available in the current Table, Figures, and Supplementary material of this manuscript (Supplementary Information Additional files 1 and 2).

\section{Declarations}

\section{Competing interests}

The authors declare that they have no known competing financial interests or personal relationships that could have appeared to influence the work reported in this paper.

\section{Author details}

${ }^{1}$ Posgrado en Ciencias del Mar y Limnología, Universidad Nacional Autónoma de México, Ciudad Universitaria, 04510 Ciudad de México, Mexico. Universidad Nacional Autónoma de México, Instituto de Ciencias del Mar y Limnología, Unidad de Procesos Oceánicos y Costeros, Ciudad Universitaria, 04510 Ciudad de México, Mexico.

Received: 15 January 2021 Accepted: 7 July 2021

Published online: 28 July 2021

\section{References}

Al-Juboury, A.L., A. Morton, W.S. Shingaly, J. Howard, B. Thusu, S. Vincent, and M. Fanning. 2020. Stratigraphy and age revision of the Pirispiki Formation, Kurdistan region, northern Iraq. Arabian Journal of Geosciences 13 (14): 593. https://doi.org/10.1007/s12517-020-05591-5.

Al-Kaaby, L.F., and B.N. Albadran. 2020. Minerals and sedimentary characteristics of Quaternary sediments of different regions in Southern Iraq. Iragi Geological Journal 53 (1A): 68-89.

Anaya-Gregorio, A., J.S. Armstrong-Altrin, M.L. Machain-Castillo, P.C. MontielGarcía, and M.A. Ramos-Vázquez. 2018. Textural and geochemical characteristics of late Pleistocene to Holocene fine-grained deep-sea sediment cores (GM6 and GM7), recovered from southwestern Gulf of Mexico. Journal of Palaeogeography 7 (3): 253-271.

Armstrong-Altrin, J.S., M.A. Ramos-Vázquez, N.Y. Hermenegildo-Ruiz, and J. Madhavaraju. 2021. Microtexture and U-Pb geochronology of detrital zircon grains in the Chachalacas beach, Veracruz state, Gulf of Mexico. Geological Journal 56 (5): 2418-2438. https://doi.org/10.1002/gj.3984.

Arribas, J., S. Critelli, E. Le Pera, and A. Tortosa. 2000. Composition of modern stream sand derived from a mixture of sedimentary and metamorphic rocks (Henares River, Central Spain). Sedimentary Geology 133 (1-2): 27-48. https://doi.org/10.1016/S0037-0738(00)00026-9.

Ayala-Pérez, M.P., J.S. Armstrong-Altrin, and M.L. Machain-Castillo. 2021. Heavy metal contamination and provenance of sediments recovered at the Grijalva River Delta, southern Gulf of Mexico. Journal of Earth System Science 130 (2). https://doi.org/10.1007/s12040-021-01570-w.

Balaram, V. 2021. Current and emerging analytical techniques for geochemical and geochronological studies. Geological Journal 55 (5): 2300-2359. https://doi.org/10.1002/gj.4005.

Banerjee, S., T.R. Choudhury, P.K. Saraswati, and S. Khanolkar. 2020. The formation of authigenic deposits during Paleogene warm climatic intervals: A review. Journal of Palaeogeography 9 (1): 27. https://doi.org/1 0.1186/s42501-020-00076-8.

Bankole, O.M., A.E. Albani, A. Meunier, M. Poujol, and A. Bekker. 2020. Elemental geochemistry and $\mathrm{Nd}$ isotopic constraints on the provenance of the basal siliciclastic succession of the Middle Paleoproterozoic Francevillian Group, Gabon. Precambrian Research 348: 105874. https:// doi.org/10.1016/j.precamres.2020.105874

Barboza-Gudiño, J.R., A. Zavala-Monsiváis, V. Castellanos-Rodríguez, and L.D. Barajas-Nigoche. 2010. Late Triassic stratigraphy and facies from northeastern Mexico: Tectonic setting and provenance. Geosphere 6 (5) 621-640. https://doi.org/10.1130/GES00545.1.

Barboza-Gudiño, J.R., A. Zavala-Monsiváis, V. Castellanos-Rodríguez, D. JaimeRodríguez, and C. Almaraz-Martínez. 2020. Subduction-related Jurassic volcanism in the Mesa Central Province and contemporary Gulf of Mexico opening. Journal of South American Earth Sciences 108: 102961. https://doi.org/10.1016/j.jsames.2020.102961.

Basu, A. 2020. Chemical weathering, first cycle quartz sand, and its bearing on quartz arenite. Journal Indian Association of Sedimentologists 37 (2): 3-14. https://doi.org/10.51710/jias.v37i2.161.

Bineli, A.T.N., V.L. Onana, S.D.N. Tang, Y.R. Bikoy, and G.E. Ekodeck. 2020. Mineralogy and geochemistry of sands of the lower course of the Sanaga River, Cameroon: Implications for weathering, provenance, and tectonic setting. Acta Geochimica. https://doi.org/10.1007/s11631-02000437-z.

Chaudhuri, A., S. Banerjee, and E. Le Pera. 2018. Petrography of Middle Jurassic to Early Cretaceous sandstones in the Kutch Basin, western India: Implications on provenance and basin evolution. Journal of Palaeogeography 7 (1): 2. https://doi.org/10.1186/s42 501-018-0002-6.

Chaudhuri, A., S. Banerjee, N. Prabhakar, and A. Das. 2020. The use of heavy mineral chemistry in reconstructing provenance: A case study from Mesozoic sandstones of Kutch Basin, India. Geological Journal 55 (12): 111. https://doi.org/10.1002/gj.3922.

Cox, R., D.R. Lowe, and R.L. Cullers. 1995. The influence of sediment recycling and basement composition on evolution of mudrock chemistry in the southwestern United States. Geochimica et Cosmochimica Acta 59 (14): 2919-2940. https://doi.org/10.1016/0016-703 7(95)00185-9.

Critelli, S. 2018. Provenance of Mesozoic to Cenozoic Circum-Mediterranean sandstones in relation to tectonic setting. Earth-Science Reviews 185: 624-648. https://doi.org/10.1016/j.earscirev.2018.07.001.

Critelli, S., J. Arribas, E. Le Pera, A. Tortosa, K.M. Marsaglia, and K.K. Latter 2003. The recycled orogenic sand provenance from an uplifted thrustbelt, Betic cordillera, southern Spain. Journal of Sedimentary Research 73 (1): 72-81. https://doi.org/10.1306/071002730072.

Critelli, S., E. Le Pera, and R.V. Ingersoll. 1997. The effects of source lithology, transport, deposition and sampling scale on the composition of southern California sand. Sedimentology 44 (4): 653-671. https://doi. org/10.1046/j.1365-3091.1997.d01-42.x.

Critelli, S., M. Martín-Martín, W. Capobianco, and F. Perri. 2021. Sedimentary history and palaeogeography of the Cenozoic clastic wedges of the Malaguide Comple, internal Betic cordillera, southern Spain. Marine and Petroleum Geology 124: 104775. https://doi.org/10.1016/j.marpetgeo.202 0.104775.

Cullers, R.L. 2000. The geochemistry of shales, siltstones and sandstones of Pennsylvanian-Permian age, Colorado, USA: Implications for provenance and metamorphic studies. Lithos 51: 305-327.

Cullers, R.L., A. Basu, and L.J. Suttner. 1988. Geochemical signature of provenance in sand-size material in soils and stream sediments near the tobacco root batholith, Montana, USA. Chemical Geology 70 (4): $335-$ 348. https://doi.org/10.1016/0009-2541(88)90123-4.

Damian, G., Z.S.G. lepure, and F. Damian. 2019. Distribution of heavy metals in granulometric fractions and on soil profiles. Carpathian Journal of Earth and Environmental Sciences 14 (2): 343-351. https://doi.org/10.264 71/cjees/2019/014/085.

Demant, A., and C. Robin. 1975. Las Fases del Vulcanismo en México. Una síntesis en relación con la Evolución Geodinámica desde el Cretácico. Revista Instituto de Geologia UNAM 75: 70-83.

Devi, S.R., M.E.A. Mondal, and J.S. Armstrong-Altrin. 2017. Geochemistry and the factors controlling on the weathering and erosion of the Barail Group of rocks, NW Manipur, India. Journal of the Indian Association of Sedimentologists 34 (1-2): 9-16.

Dew, R., C.K. Morley, T.A. Myint, and A. Collins. 2019. Age and provenance of the Chaung Magyi Group, Yeywa Dome, Myanmar, based on U-Pb dating of detrital zircons. Journal of Asian Earth Sciences 184: 103967. https://doi.org/10.1016/j.jseaes.2019.103967. 
Dickinson, W.R. 1970. Interpreting detrital modes of graywacke and arkose. Journal of Sedimentary Petrology 40: 695-707.

Ekoa Bessa, A.Z., G. Nguetchoua, A.K. Janpou, Y.A. El-Amier, O.N.N.M. Nguetnga, U.R. Kayou, S.B. Bisse, E.C.N. Mapuna, and J.S. ArmstrongAltrin. 2021. Heavy metal contamination and its ecological risks in the beach sediments along the Atlantic Ocean (Limbe coastal fringes, Cameron). Earth Systems and Environment 5 (2): 433-444. https://doi. org/10.1007/s41748-020-00167-5.

Escalona-Alcázar, F.J., L. Solari, J.C. García y Barragán, C. Carrillo-Castillo, J. Bluhm-Gutiérrez, P. García-Sandoval, A.F. Nieto-Samaniego, and E.P. Núñez-Peña. 2016. The Paleocene-early Oligocene Zacatecas conglomerate, Mexico: Sedimentology, detrital zircon U-Pb ages, and sandstone provenance. International Geology Review 58: 826-848, 7, DOl: https://doi.org/10.1080/00206814.2015.1125809.

Fedo, C.M., H.W. Nesbitt, and G.M. Young. 1995. Unraveling the effects of potassium metasomatism in sedimentary rocks and paleosols, with implications for paleoweathering conditions and provenance. Geology 23 (10): 921-924. https://doi.org/10.1130/0091-7613(1995)023<0921: UTEOPM > 2.3.CO;2.

Folk, R.L., and W.C. Ward. 1957. Brazos river bar, a study in the significance of grain-size parameters. Journal of Sedimentary Petrology 27 (1): 3-26. https://doi.org/10.1306/74D70646-2B21-11D7-8648000102C1865D.

Gärtner, A., N. Youbi, M. Villeneuve, A. Sagawe, M. Hofmann, A. Mahmoudi, M.A. Boumehdi, and U. Linnemann. 2017. The zircon evidence of temporally changing sediment transport - The NW Gondwana margin during Cambrian to Devonian time (Aoucert and Samara areas, Moroccan Sahara). International Journal of Earth Sciences 106 (8): 27472769. https://doi.org/10.1007/s00531-017-1457-x.

Gazzi, P. 1966. Le arenarie del flysch sopracretaceo dell'Appennino modensese: Correlazioni con il flysch di Monghidoro. Mineralogica et Petrographica Acta 12: 69-97.

Girty, G.H., D.L. Ridge, C. Knaack, D. Johnson, and R.K. Al-Riyami. 1996. Provenance and depositional setting of Paleozoic chert and argillite, Sierra Nevada, California. Journal of Sedimentary Research 66: 107-118.

Harnois, L. 1988. The CIW index: A new chemical index of weathering. Sedimentary Geology 55 (3-4): 319-322. https://doi.org/10.1016/0037-073 8(88)90137-6.

Hernández-Hinojosa, V., P.C. Montiel-García, J.S. Armstrong-Altrin, R. Nagarajan, and J.J. Kasper-Zubillaga. 2018. Textural and geochemical characteristics of beach sands along the western Gulf of Mexico, Mexico. Carpathian Journal of Earth and Environmental Sciences 13 (1): 161-174. https://doi.org/10.26471/cjees/2018/013/015.

Hoskin, P.W.O., and T.R. Ireland. 2000. Rare earth element chemistry of zircon and its uses as a provenance indicator. Geology 28 (7): 627-630. https:// doi.org/10.1130/0091-7613(2000)28<627:REECOZ>2.0.CO;2.

Hossain, H.M.Z. 2019. Major, trace, and REE geochemistry of the Meghna River sediments, Bangladesh: Constraints on weathering and provenance. Geological Journal 55 (3): 3321-3343. https://doi.org/10.1 002/gj.3595.

Hudson, P.F. 2003. Event sequence and sediment exhaustion in the lower Panuco Basin, eastern Mexico. Catena 52 (1): 57-76. https://doi.org/10.1 016/50341-8162(02)00145-5.

Jarvis, K.E. 1988. Inductively coupled plasma mass spectrometry: A new technique for the rapid or ultra-level determination of the rare-earth elements in geological materials. Chemical Geology 68 (1-2): 31-39. https://doi.org/10.1016/0009-2541(88)90084-8.

Juárez-Arriaga, E., T.F. Lawton, Y.Z.E. Ocampo-Díaz, D.F. Stockli, and L. Solari. 2019. Sediment provenance, sediment-dispersal systems, and major arcmagmatic events recorded in the Mexican foreland basin, north-central and northeastern Mexico. International Geology Review 61 (17): 21182142. https://doi.org/10.1080/00206814.2019.1581848.

Karlik, M., I. Gyollai, A. Vancsik, K. Fintor, Z. Szalai, M. Mîndrescu, I. Grădinaru, S. Vágási, G. Bozsó, M. Polgári, and E. Pál-Molnár. 2021. High resolution mineralogical characterization of sediments - Lake Bolătău-Feredeu (Romania). Carpathian Journal of Earth and Environmental Sciences 16 (1): 199-210. https://doi.org/10.26471/cjees/2021/016/167.
Kasper-Zubillaga, J.J., R.G. Martínez-Serrano, E. Arellano-Torres, L.F. ÁlvarezSánchez, D.P. Andrade, A.G. Bermúdez, and L. Carlos-Delgado. 2021. Petrographic and geochemical analysis of dune sands from southeastern, Oaxaca, Mexico. Geological Journal 56 (6): 3012-2034. https://doi.org/10.1002/gj.4086.

Katz, A., and G.M. Friedman. 1965. The preparation of stained acetate peels for the study of carbonate rocks. Journal of Sedimentary Petrology 35 (1): 248-249. https://doi.org/10.1306/74D71230-2B21-11D7-8648000102C1 865D.

Kettanah, Y.A., J.S. Armstrong-Altrin, and F.A. Mohammad. 2021. Petrography and geochemistry of siliciclastic rocks of the middle Eocene Gercus Formation, northern Iraq: Implications for provenance and tectonic setting. Geological Journal 56 (5): 2528-2549. https://doi.org/10.1002/gj.3880

Lawton, T.F., and R.S. Molina-Garza. 2014. U-Pb geochronology of the type Nazas Formation and superjacent strata, northeastern Durango, Mexico: Implications of a Jurassic age for continental-arc magmatism in NorthCentral Mexico. Geological Society of America Bulletin 126 (9-10): 11811199. https://doi.org/10.1130/B30827.1

Lee, Y.I., J. Yi, and T. Choi. 2015. Provenance analysis of Lower Cretaceous Sindong Group sandstones in the Gyeongsang Basin, Korea, using integrated petrography, quartz SEM-Cathodoluminescence, and zircon $\mathrm{Zr} / \mathrm{Hf}$ analysis. Journal of Sedimentary Research 85 (5): 529-543. https:// doi.org/10.2110/jsr.2015.36

Ludwig, K.L. 1998. On the treatment of concordant uranium-Lead ages. Geochimica et Cosmochimica Acta 62 (4): 665-676. https://doi.org/10.101 6/50016-7037(98)00059-3.

Ludwig, K.R. 2003. User's manual for Isoplot 3.00: A geochronological toolkit for Microsoft excel, special publication 4a. Berkeley: Berkeley geochronological Centre.

Machain-Castillo, M., A. Ruiz-Fernández, A. Gracia, J. Sanchez-Cabeza, A. Rodríguez-Ramírez, H. Alexander-Valdés, L. Pérez-Bernal, X. NavaFernández, L. Gómez-Lizárraga, L. Almaraz-Ruiz, P. Schwinge, and D. Hollander. 2019. Natural and anthropogenic oil impacts on benthic foraminifera in the southern Gulf of Mexico. Marine and Environmental Research 149: 111-125. https://doi.org/10.1016/j.marenvres.2019.06.006.

Madhavaraju, J., J.S. Armstrong-Altrin, R.P. Pillai, and T. Pi-Puig. 2021. Geochemistry of sands from the Huatabampo and Altata beaches, Gulf of California, Mexico. Geological Journal 56 (5): 2398-2417. https://doi. org/10.1002/gj.3864

Madhavaraju, J., S.P. Rajendra, Y.I. Lee, E.R. Montoya, S. Ramasamy, and R.F. SantaCruz. 2020. Mineralogy and geochemistry of clastic sediments of the Terani Formation, Cauvery Basin, southern India: Implications for paleoweathering, provenance and tectonic setting. Geosciences Journal 24 (6): 651-667. https://doi.org/10.1007/s12303-019-0047-2

McRivette, M.W., A. Yin, X. Chen, and G.E. Gehrels. 2019. Cenozoic basin evolution of the Central Tibetan Plateau as constrained by U-Pb detrital zircon geochronology, sandstone petrology, and fission-track thermochronology. Tectonophysics 751: 150-179. https://doi.org/10.101 6/j.tecto.2018.12.015

Monreal-Gómez, A., D. Salas-de-León, A. Padilla-Pilotze, and M. AlatorreMendieta. 1992. Hydrography and estimation of density currents in the southern part of the bay of Campeche, Mexico. Ciencias Marinas 18 (4): 115-133. https://doi.org/10.7773/cm.v18i4.908.

Müller, W., M. Shelley, P. Miller, and S. Broude. 2009. Initial performance metrics of a new custom-designed ArF excimer LA-ICPMS system coupled to a two-volume laser-ablation cell. Journal of Analytical Atomic Spectrometry 24 (2): 209-214. https://doi.org/10.1039/B805995K.

Mustafa, R.K., and F.H. Tobia. 2020. Geochemical application in unravelling paleoweathering, provenance and environmental setting of the shale from Chia Gara Formation, Kurdistan region, Iraq. Iraqi Geological Journal 53 (1A): 90-116. https://doi.org/10.46717/igj.53.1a.R7.2020.01.28

Nesbitt, H.W., and G.M. Young. 1982. Early Proterozoic climates and plate motions inferred from major element chemistry of lutites. Nature 299 (5885): 715-717. https://doi.org/10.1038/299715a0.

Paton, C., J.D. Woodhead, J.C. Hellstrom, J.M. Hergt, A. Greig, and R. Maas. 2010. Improved laser ablation U-Pb zircon geochronology through 
robust downhole fractionation correction. Geochemistry Geophysics Geosystems 11 (3): Q0AA06. https://doi.org/10.1029/2009GC002618.

Patra, A., and A. Shukla. 2020. Geochemical signatures of late Paleocene sandstones from the Sanu formation, Jaisalmer Basin, western India: Implication for provenance, weathering and tectonic setting. Journal of Earth System Science 129 (1): 81. https://doi.org/10.1007/s12040-02 0-1358-4.

Petrus, J.A., and B.S. Kamber. 2012. VizualAge: A novel approach to laser ablation ICP-MS U-Pb geochronology data reduction. Geostandards and Geoanalytical Research 36 (3): 247-270. https://doi.org/10.1111/j.1 751-908X.2012.00158.x.

Potter-McIntyre, S.L., J.R. Breeden, and D.H. Malone. 2018. A Maastrichtian birth of the ancestral Mississippi River system: Evidence from the U-Pb detrital zircon geochronology of the McNairy sandstone, Illinois, USA. Cretaceous Research 91: 71-79. https://doi.org/10.1016/..cretres.2018.05.010.

Rivera-Gómez, M.A., J.S. Armstrong-Altrin, S.P. Verma, and L. Díaz-González. 2020. APMDisc: An online computer program for the geochemical discrimination of siliciclastic sediments from active and passive margins. Turkish Journal of Earth Sciences 29: 550-578. https://doi.org/10.3906/ yer-1908-15.

Rosales-Hoz, L., A. Carranza-Edwards, R. Martínez-Serrano, M.A. Alatorre, and J.S. Armstrong-Altrin. 2015. Textural and geochemical characteristics of continental margin sediments in the SW Gulf of Mexico: Implications for source and seasonal change. Environmental Monitoring Assessment 187 (205): 1-19.

Roser, B.P., and R.J. Korsch. 1988. Provenance signatures of sandstone mudstone suites determined using discrimination function analysis of major element data. Chemical Geology 67 (1-2): 119-139. https://doi. org/10.1016/0009-2541(88)90010-1.

Rubio-Cisneros, I.I., and T.F. Lawton. 2011. Detrital zircon U-Pb ages of sandstones in continental red beds at Valle de Huizachal, Tamaulipas, NE Mexico: Record of Early-Middle Jurassic arc volcanism and transition to crustal extension. Geosphere 7 (1): 159-170. https://doi.org/10.1130/ GES00567.1

Servicio Geológico Mexicano. 2008. Carta Geológico-Minera Ciudad Victoria F14-2, Tamps, N. L. y S.L.P. Escala. Vol. 1, 250000.

Sieck, P., R. López-Doncel, P. Dávila-Harris, A. Aguillón-Robles, K. Wemmer, and R.C. Maury. 2019. Almandine garnet-bearing rhyolites associated to bimodal volcanism in the Mesa central of Mexico: Geochemical, petrological and geochronological evolution. Journal of South American Earth Sciences 92: 310-328. https://doi.org/10.1016/j.jsames.2019.03.018.

Silva-Romo, G., C.C. Mendoza-Rosales, E. Campos-Madrigal, A. Morales-Yáñez, A.I. Torre-González, and J.I. Nápoles-Valenzuela. 2018. Recycling of Amazonian detrital zircons in the Mixteco Terrane, southern Mexico: Paleogeographic implications during Jurassic-Early Cretaceous and Paleogene times. Journal of South American Earth Sciences 83: 210-226. https://doi.org/10.1016/j.jsames.2018.02.011

Sláma, J., J. Košler, D.J. Condon, J.L. Crowley, A. Gerdes, J.M. Hanchar, M.S.A. Horstwood, G.A. Morris, L. Nasdala, N. Norberg, U. Schaltegger, B. Schoene, M.N. Tubrett, and M.J. Whitehouse. 2008. Plešovice zircon - A new natural reference material for $\mathrm{U}-\mathrm{Pb}$ and $\mathrm{Hf}$ isotopic microanalysis. Chemical Geology 249 (1-2): 1-35. https://doi.org/10.1016/j.chemgeo.2 007.11.005.

Solari, L.A., A. Gómez-Tuena, J.P. Bernal, O. Pérez-Arvizu, and M. Tanner 2010. U-Pb zircon geochronology by an integrated LA-ICPMS microanalytical workstation: Achievements in precision and accuracy. Geostandard and Geoanalytical Research 34 (1): 5-18. https://doi.org/1 0.1111/j.1751-908X.2009.00027.X.

Solari, L.A., J.D. Keppie, F. Ortega-Gutiérrez, K.L. Cameron, and R.K. Lopez. 2004. Similar to $990 \mathrm{Ma}$ peak granulite metamorphism and amalgamation of Oaxaquia, Mexico: U-Pb zircon geochronological and common Pb isotopic data. Revista Mexicana de Ciencias Geologicas 21: 212-225.

Solari, L.A., F. Ortega-Gutiérrez, M. Elías-Herrera, C. Ortega-Obregón, C. Macías-Romo, and M. Reyes-Salas. 2014. Detrital provenance of the Grenvillian Oaxacan Complex, southern Mexico: A zircon perspective.
International Journal of Earth Sciences 103 (5): 1301-1315. https://doi. org/10.1007/s00531-013-0938-9.

Tawfik, H.A., M.K. Salah, W. Maejima, J.S. Armstrong-Altrin, A.-M.T. AbdelHameed, and M.M.E. Ghandour. 2018. Petrography and geochemistry of the Lower Miocene Moghra sandstones, Qattara depression, North Western Desert, Egypt. Geological Journal 53 (5): 1938-1953. https://doi. org/10.1002/gj.3025.

Taylor, S.R., and S.M. McLennan. 1985. The continental crust: Its composition and evolution. Oxford: Blackwell Scientific Publishers.

Tobia, F.H., and S.S. Shangola. 2019. Geochemistry of sandstones from Beduh Formation in northern thrust zone, Kurdistan region, northern Iraq: Provenance and tectonic setting. Iraqi Geological Journal 52 (1): 1-25.

Torres-Sánchez, D., S.K. Verma, T.L. Barry, S.P. Verma, and J.R. TorresHernández. 2020. ${ }^{40} \mathrm{Ar} /{ }^{39} \mathrm{Ar}$ geochronology and petrogenesis of the sierra de San Miguelito volcanic complex, Mesa central, Mexico. Lithos 370-371: 105613.

Turzewski, M.D., K.W. Huntington, A. Licht, and K.A. Lang. 2020. Provenance and erosional impact of quaternary megafloods through the YarlungTsangpo gorge from zircon U-Pb geochronology of flood deposits, eastern Himalaya. Earth and Planetary Science Letters 535: 116113. https://doi.org/10.1016/j.epsl.2020.116113.

Vega-Granillo, R., A. Sarmiento-Villagrana, J.R. Vidal-Solano, E. Araux-Sánchez, and A. Bourjac-de-Anda. 2020. Northern limit of Gondwana in northwestern Mexico from detrital zircon data. Gondwana Research 83: 232-247. https://doi.org/10.1016/j.gr.2020.02.007.

Verlekar, P., and M. Kotha. 2020. Provenance, tectonics and palaeoenvironment of Mesoproterozoic Saundatti quartzite member of Kaladgi Basin, India: A petrographic view. Journal of the Indian Association of Sedimentologists 37 (2): 91-102. https://doi.org/10.51710/ jias.v37i2.101.

Verma, S.K., K.G.A. Fimbres, D. Torres-Sánchez, J.R.T. Hernández, S.A. TorresSánchez, and H. López-Loera. 2020. Geochemistry and petrogenesis of Oligocene felsic volcanic rocks from the Pinos volcanic complex, Mesa central, Mexico. Journal of South American Earth Sciences 102: 102704. https://doi.org/10.1016/j.jsames.2020.102704.

Verma, S.K., D. Torres-Sánchez, K.R. Hernández-Martínez, V.P. Malviya, P.K. Singh, J.R. Torres-Hernández, and B.A. Rivera-Escota. 2021. Geochemistry of Eocene felsic volcanic rocks from the Mesa Virgen-Calerilla, Zacatecas, Mexico: Implications for the magma source and tectonic setting. Geological Journal. https://doi.org/10.1002/gj.4233.

Wang, Q., C.J. Spencer, R. Hamdidouche, G. Zhao, N.J. Evans, and B.J. McDonald. 2020. Detrital zircon U-Pb-Hf data from Cambrian sandstones of the Ougarta Mountains Algeria: Implication for palaeoenvironment. Geological Journal. https://doi.org/10.1002/gj.3899.

Weber, B., E.E. Scherer, C. Schulze, V.A. Valencia, P. Montecinos, K. Mezger, and J. Ruiz. 2010. U-Pb and Lu-Hf isotope systematics of lower crust from Central-Southern Mexico - Geodynamic significance of Oaxaquia in a Rodinia realm. Precambrian Research 182 (1-2): 149-162. https://doi. org/10.1016/j.precamres.2010.07.007.

Wentworth, C.K. 1922. A scale of grade and class terms for clastic sediments. Journal of Geology 30 (5): 377-392. https://doi.org/10.1086/622910.

Yáñez-Arancibia, A., J.W. Day, and B. Currie-Alder. 2009. The GrijalvaUsumacinta river delta functioning: Challenge for coastal management Ocean Yearbook 23 (1): 473-501. https://doi.org/10.1163/2211600190000205

Zavala-Monsiváis, A., J.R. Barboza-Gudiño, F. Velasco-Tapia, and M.E. GarcíaArreola. 2012. Sucesión volcánica jurásica en el área de charcas, San Luis Potosí: Contribución al entendimiento del arco Nazas en el noreste de México. Boletín de la Sociedad Geológica Mexicana 64 (3): 277-299. https://doi.org/10.18268/BSGM2012v64n3a2.

Zeng, S., J. Wang, W. Chen, X. Fu, X. Feng, C. Song, D. Wang, and W. Sun. 2019. Geochemical characteristics of Early Cretaceous marine oil shale from the Changshe Mountain area in the northern Qiangtang Basin, Tibet: Implications for palaeoweathering, provenance, tectonic setting, and organic matter accumulation. Geological Journal 55 (4): 3229-3246. 
Zeng, S., J. Wang, X. Fu, W. Chen, C. Song, X. Feng, and D. Wang. 2020. Geochemistry and detrital zircon geochronology of the Jurassic clastic rocks of the northern Qiangtang Basin, northern Tibet: Implication for palaeoenvironment, provenance, and tectonic setting. Geological Journal 56 (6): 2869-2887. https://doi.org/10.1002/gj.4074.

\section{Publisher's Note}

Springer Nature remains neutral with regard to jurisdictional claims in published maps and institutional affiliations.

Submit your manuscript to a SpringerOpen ${ }^{\circ}$ journal and benefit from:

- Convenient online submission

- Rigorous peer review

- Open access: articles freely available online

- High visibility within the field

- Retaining the copyright to your article

Submit your next manuscript at $\boldsymbol{\nabla}$ springeropen.com 